\title{
UN COMUNERO ANTE EL PATÍBULO: VIDA, MUERTE Y MEMORIA DE FRANCISCO MERCADOR, CAPITÁN DE LA COMUNIDAD DE BAZA
}

\author{
JaVier CASTillo FernándeZ ${ }^{1}$ \\ Archivo General de la Región de Murcia
}

Recibido: 31 de julio de 2020

Aceptado: 3 de septiembre de 2020

\section{Resumen}

Se estudia la trayectoria vital del que fuera principal líder de la revuelta comunera en Baza: un personaje singular, que usó en vida dos nombres indistintamente, con una trayectoria bélica importante durante la época fronteriza, la guerra de conquista del Reino de Granada y las empresas en el norte de África, así como con una notable relevancia social e institucional en esa ciudad granadina. También se analiza y transcriben sus últimas voluntades, otorgadas inmediatamente antes de ser ejecutado por orden del marqués de Mondéjar, capitán general de Granada, que aplacó la revuelta. Por último, se rastrea la huella histórica que dejó el personaje, manipulada tanto por su familia (que lo trasmudó en hijo bastardo de un aristócrata) como por sus detractores (que lo convirtieron en un simple maleante).

\section{Palabras clave}

Comunidades de Castilla, Reino de Granada, Biografías, Genealogía, Falsificación histórica

\begin{abstract}
This work addresses the vital trajectory of the main leader of the revolt of the Comuneros in Baza: a singular personality, who during his life used two names interchangeably. This character developed an important military trajectory during the frontier era, the conquest of the Kingdom of Granada and the military actions in Northern Africa, as well as a notable social and institutional relevance in the city of Baza. We also analyse and transcribe his last will, granted immediately before being executed by order of the marquis of Mondéjar, captain general of Granada, who placated the revolt. Lastly, we follow the historical footprint that this character left, which was manipulated both by his family - who transmutated him into the bastard son of an aristocrat - and his detractors - who turned him into a simple miscreant.
\end{abstract}

\section{Keywords}

Communities of Castilla, Kingdom of Granada, Biographies, Genealogy, Historical falsification

\footnotetext{
Archivo General de la Región de Murcia. Avda. de los Pinos, 4, 30009, Murcia. Correo electrónico: javierc.castillo@carm.es. ORCID: https://orcid.org/0000-0001-6849-4586.
} 


\begin{abstract}
Resumo
É analisada a trajetoria de vida de quem fosse o principal lider da revolta comuneira em Baza: um personagem singular, que usou durante a sua vida dois nomes de forma intercambiável, com um percurso bélico importante durante a época fronteiriza, a guerra da conquista do Reino de Granada e as empresas no norte da África, bem como uma notável relevância social e institucional na cidade de Baza. Também são analisadas e transcritas as suas últimas vontades, concedidas imediatamente antes de ser executado pela ordem do marquês de Mondéjar, capitão geral de Granada, quem aplacou a revolta. Finalmente, segue-se o rastro histórico que deixou o personagem, manipulado quer pela sua família (que o transformou no filho bastardo de um aristócrata) quer pelos seus detratores (que o tornaram em um simples malfeitor).
\end{abstract}

Palavras-chave

Comunidades de Castela, Reino de Granada, Biografias, Genealogia, Falsificação Histórica

\title{
1. Una persona, dos identidades: Francisco de Baeza y Francisco Mercador. Re- construcción biográfica
}

Francisco Mercador nació en el último tercio del siglo XV en Cazorla, localidad cabecera del Adelantamiento del mismo nombre: un territorio castellano en la frontera de Granada, inscrustado entre los Reinos de Jaén y Murcia, que pertenecía al Arzobispado de Toledo². Esta demarcación constituyó durante la Baja Edad Media una de las cabezas de puente, de ataque y de defensa, frente a los territorios nororientales del sultanato nazarí dominados por madinat Basta ${ }^{3}$. Como la mayor parte de los habitantes de aquellas tierras se curtió desde joven ${ }^{4}$ en las escaramuzas y encuentros bélicos propios de la frontera. Participó de forma muy activa en la guerra de conquista del Reino de Granada, donde cayó cautivo del enemigo ${ }^{5}$ y tuvo una destacada participación en el largo asedio de la ciudad de Baza, donde según la Corona: "bençistes dos desafíos que tubistes con çiertos moros y salistes a ellos, la una vez del Castillo del Artillería, donde posábades, y la otra vez del Castillo de la Noguera";; posiblemente encuadrado en las tropas que

\footnotetext{
2 García Guzmán, María del Mar, El adelantamiento de Cazorla en la Baja Edad Media: un señorio eclesiástico en la frontera castellana.

3 Para la cambiante frontera en este sector, entre los siglos XIII al XV, véase CASTILlo FernándeZ, Javier, "La articulación territorial del noreste del Reino de Granada de la Edad Media a la Moderna".

4 Un documento regio reconocía, años después, su temprano y destacado currículo como frontero: "desde que fuistes de hedad de quinze años servistes al rey don Fernando, mi señor, que aya santa gloria, en la guerra que tuvieron con el rey y moros del reyno de Granada, donde derramastes en su serviçio asaz de vuestra sangre e fezistes otros muchos serviçios señalados”. Véase la nota siguiente.

5 Archivo General de Simancas, Registro General del Sello (en adelante AGS, RGS), 1511-01, fol. 78.

6 IBIDEM, 1511-01, fol. 113. Para delimitación del cerco, la situación de los campamentos cristianos (uno de ellos, denominado de la Artillería, a cargo del marqués de Cádiz) así como para la identificación de algunas de las torres o "castillos" erigidos por los sitiadores (entre los que no figura este de la Noguera), véase Acosta Echeverría, Manuel y Tristán García, Francisco: "El escudo de Baza: una representación de la realidad histórica (el cerco y la toma de 1489)".
} 
comandaba el adelantado de Cazorla, don Pedro Hurtado de Mendoza, hermano del cardenal de España?

Como muchos de los participantes en el cerco de la ciudad, nuestro personaje, al igual que hicieron sus padres, parientes y otros convecinos ${ }^{8}$, dicidió instalarse como colono en la ciudad recién conquistada. En recompensa a sus destacados servicios bélicos, el joven Mercador recibió una suculenta merced de casas y tierras en el repartimiento de Baza, por orden expresa de los Reyes Católicos, que ordenaron a los repartidores de la ciudad entregar "a su hijo de Diego Mercador, vesino de Caçorla":

"en esa çibdad e en sus términos una vesindad, como avéis dado o diéredes a qualesquier escudero que en ella se ha avezinado o avezindare, por quanto nuestra voluntad es que asy se haga e cunpla".

Esta merced, por su cuantía le equiparaba a una de las categorías de colonos más importantes: la de los escuderos de la guardas ${ }^{10}$; y es más que probable que esta gracia real se le otorgara al no cumplir alguno de los requisitos exigidos a los repobladores, posiblemente el de estar casado. En efecto, en ejecución del mandato regio, el 7 de marzo de 1494, Gonzalo de Cortinas, el responsable del repartimiento de los bienes confiscados a los musulmanes bastetanos, dio posesión a Francisco Mercador, hijo de Diego Mercador, de unas casas y un corral en el arrabal de San Juan (el barrio extramuros donde se asentaron tanto los mudéjares expulsados del centro de la ciudad, o medina,

\footnotetext{
Según el cronista Hernando del Pulgar, el adelantado comandaba una tropa de 500 jinetes del cardenal don Pedro González de Mendoza, arzobispo de Toledo, y durante la primera batalla de las huertas de Baza, le acompañaban -entre otros- la gente de a pie y de a caballo del Adelantamiento de Cazorla. El mismo cronista afirma que en la revista previa al cerco figuraba al frente de 600 jinetes y 400 peones. Magaña Visbal, Luis, Baza histórica, p. 253.

8 El contingente de familias repobladoras asentadas en Baza procedentes de Cazorla es el segundo en importancia numérica, con un total de 69 , lo que supuso más del $10 \%$ del total de colonos. Miralles Lozano, María Eulalia y Tristán García, Francisco, "La repoblación de Baza: el repartimiento de los Reyes Católicos...", p. 194.

9 Real cédula de los Reyes Católicos otorgada en Alcaudete el 25 de mayo de 1492. Archivo Municipal de Baza (en adelante AMB), Libro de repartimiento de la ciudad (en adelante LRB), fol. 93.

10 En el repartimiento de Baza - como en buena parte de las ciudades granadinas colonizadas por entonces- se distinguían cuatro grupos sociales, a los que correspondían más o menos bienes en el reparto de acuerdo con la siguiente jerarquía: los caballeros principales (un total de 24 personajes de la aristocracia y la alta administración), los escuderos de los guardas, continos y criados reales (99 individuos), los 34 caballeros criados de don Enrique Enríquez (equiparados en el reparto con los anteriores), los escuderos de ciudades o caballeros (97) y los peones (324). Castillo Fernández, Javier, "El origen del concejo y la formación de la oligarquía ciudadana en Baza (1492-1520)", p. 54. Véase, aunque con alguna diferencia en los guarismos, Miralles Lozano, María Eulalia y Tristán García, Francisco, "La repoblación de Baza", p. 202. Para las categorías sociales surgidas de la colonización granadina, véase Peinado SAntaella, Rafael Gerardo, "El Reino de Granada después de la conquista: la sociedad repobladora según los "libros de repartimiento"".
} 
como los primeros "cristianos nuevos de moros")"; así como distintos fundos en los diversos pagos que circundaban la ciudad ${ }^{12}$. Es interesante señalar que el joven escudero recibió justo el doble de lo que le correspondió a sus padres, Diego Mercador e Isabel Yáñez, también asentados como colonos, pero con una donación correspondiente a la categoría inmediatamente inferior de los "caballeros de las ciudades"13.

No es mucho lo que conocemos de la estirpe de los Mercador de Cazorla ${ }^{14}$, más allá de su condición cercana a la hidalguía y a su más que probable ascendencia judeoconversa ${ }^{15}$, como otras muchas estirpes asentadas en el Reino de Granada ${ }^{16}$. De los primeros años de Francisco Mercador como nuevo vecino de Baza apenas hay testimonios, puesto que las fuentes documentales escasean para ese periodo. Debió ser a comienzos del siglo XVI cuando casó con una eminente dama, Teresa de Buiza ${ }^{17}$, que acababa de enviudar del caballero Juan Núñez del Alameda y que contaba con dos hijos pequeños ${ }^{18}$. Alameda, alcaide de la localidad de Cea (Léon) y ayo del primogénito del marqués de Denia, había sido distinguido también con importantes mercedes en el repartimiento

11 El cuerpo de casas y un corral concedidos a Mercador lindaban con casas de la Cordobesa y con la casa y huerta de Gonzalo de Cortinas, "natural de Baza", dos del medio centenar de musulmanes de Baza que se bautizaron tempranamente para acceder a bienes del repartimiento o para casar con alguno de los colonos cristianos. Para este fenómeno véase Pérez Boyero, Enrique, "Notas y documentos sobre las conversiones voluntarias de mudéjares granadinos".

12 AMB, LRB, fol. 93. Suponían cuarenta fanegas de tierras de secano y regadío, dos aranzadas de viñas y una huerta de cien estadales.

13 Diego Mercador figura en el repartimiento como uno de los caballeros procedentes de Cazorla (Ibidem, fols. 414 y 448v). El 26 de febrero de 1493 se les dio posesión de una casas y un corral en el mismo arrabal de San Juan, "en la calle que va al osario de los moros", así como de 20 fanegas y 4 celemines de tierras, 3/4 de aranzada de viñas y 380 estadales de huerta (Ibidem, fol. 204).

14 Entre los regidores de esa villa durante el bienio 1513-1514 figura un Fernando Mercador (GARCíA Guzmán, María del Mar, El adelantamiento de Cazorla en la Baja Edad Media, p. 249), que probablemente es el mismo Hernando Mercador, vecino de Cazorla, que depuso a favor de la mitra toledana en un interrogatorio del año 1528 en relación con el largo pleito entre el obispado de Guadix y el arzobispado de Toledo por la posesión de la abadía de Baza. También lo hizo, por cierto, aunque en otra probanza de en torno a 1508 que figura en el mismo legajo, nuestro protagonista. Archivo Diocesano de Guadix, leg. 3824: "La relaçion del pleito questá en el Consejo entre el obispo de Guadix con el arçobispo de Toledo y con el deán y cabildo de la dicha yglesia de Toledo".

15 Así se apunta en CAstillo FernÁndeZ, Javier, "«Negocios de familia»: el perfil institucional y social de los mayordomos de propios del Reino de Granada”, p. 41. Este apellido aparece con relativa frecuencia entres los conversos de otras localidades jienenses, como Úbeda y Baeza. Porras Arboledas, Pedro, Las comunidades conversas de Úbeda y Baeza en el siglo XVI.

16 Soria Mesa, Enrique, "Los judeoconversos granadinos en el siglo XVI".

17 Era hija de don Álvaro de Buiza, señor de Villamartín de Don Sancho (López DE Haro, Alonso: Segunda parte del nobiliario genealógico de los reyes y títulos de España, p. 15). El apellido Buiza era muy común en esta localidad leonesa y estaba vinculado a una suerte de señorío colectivo, algunos de cuyos miembros fueron clientes del linaje de los Enríquez, almirantes de Castilla (SÁnchez Badiola, Juan José, Nobiliario de la Montaña leonesa, p. 169). En 1502 se falló un pleito entre Pedro de Buiza, en nombre de los hijos de Álvaro de Buiza, difunto, y de Leonor de Castellanos (entre los que se cita a Teresa), con Gonzalo de Buiza, por la herencia y posesión de determinadas partes del señorío de Villamartín. Archivo de la Real Chancillería de Valladolid, Registro de ejecutorias, caja 172,4.

18 Espinar Moreno, Manuel, "Partición de herencia de los repobladores bastetanos Juan Núñez de Alameda y Teresa de Boyça". 
de Baza, al máximo nivel social de los llamados "caballeros principales": el segmento superior de los colonos $^{19}$. Estas propiedades se vieron acrecentadas entre 1493 y 1496 al recibir como ayuda a su casamiento por parte de su señor, don Bernardo de Sandoval y $\operatorname{Rojas}^{20}$, la mitad de las casi 150 fanegas de tierra que este aristócrata había recibido en el repartimiento de Baza. Todo lo cual nos indica que Mercador contaba con una consideración social relevante que le permitió enlazar con una familia de la baja nobleza. De su matrimonio con Teresa de Buiza nacieron al menos dos hijas: Juana y Luisa de Buiza. En cualquier caso, nuestro protagonista debió enviudar pronto, antes del año 1508 , fecha en la cual sus hijastros también eran menores de edad ${ }^{21}$.

Es precisamente en ese año cuando encontramos de nuevo referencias a nuestro personaje y a una de las singularidades con la que aparece en la documentación, así como en su intereacción personal y en su vida cotidiana: el uso indistinto y simultáneo -pero nunca de forma conjunta- de dos apellidos, Mercador y Baeza ${ }^{22}$. Singularidad que se produce durante un periodo concreto de su vida que discurre entre los años 1508 y 1517, para a partir de este año volver a utilizar solamente el apellido Mercador. Inicialmente, las abundantes referencias que figuran en las fuentes hacían supone ${ }^{23}$ que se trataba de dos personas distintas, pero se ha podido constatar fehacientemente que se trata de un mismo sujeto ${ }^{24}$. Resulta realmente asombroso evidenciar cómo nuestro personaje utilizó durante casi una década - es posible, que desde antes, pero no contamos con documentos sobre él entre los años 1494 y 1507-, de forma indistinta y simultánea en el tiempo, sus dos patronímicos, sin que podamos establecer una pauta de uso. Hemos podido contabilizar más de ciento veinte referencias documentales entre los años 1508 y 1520 -además de algunas posteriores a su fallecimiento-, procedentes de diversas fuentes (documentación municipal, protocolos notariales, documentos reales y familiares). De

\footnotetext{
19 AMB, LRB, fol. 221v. Recibió cuatro caballerías, que contabilizaban más de 82 fanegas de tierras.

20 El futuro II marqués de Denia estaba casado con doña Francisca Enríquez, una de las cuatro hijas del matrimonio de don Enrique Enríquez de Guzmán, tío y mayordomo mayor de Fernando el Católico, y de doña María de Luna: la estirpe que tras la conquista dominó los destinos de Baza y su tierra durante más de un siglo. Véase, al respecto, los trabajos de Tristán García, Francisco, "Enrique Enríquez, el primer repoblador de los Reyes Católicos", LÁzaro Damas, María Soledad, "Poder y mecenazgo nobiliario en Baza: Doña María de Luna" y CAstillo Fernández, Javier, "El origen del concejo y la formación de la oligarquía ciudadana en Baza".

21 Juan Bautista de la Alameda y su hermana Isabel quedaron bajo la tutoría de Juan de Escobar, escribano público de Baza. Ambos pleitearon con su padrastro Mercador por la propiedad de una casa en Baza. AGS, RGS, 1513-09, fol. 350.

22 Este apellido pertenecía también sin duda a su estirpe, pues su hermano, canónigo en la iglesia colegial de Baza, se llamaba Sebastián de Baeza, así como su más que probable hermana, Mayor de Baeza, esposa del escribano Juan Pérez de Pareja, originario también de Cazorla.

23 Castillo Fernández, Javier, "El origen del concejo y la formación de la oligarquía ciudadana en Baza", p. 69 .

24 Así, por ejemplo, si rastreamos las actas municipales buscando los nombres de los distintos jurados que asisten a las sesiones del cabildo, se comprueba que cuando aparece Francisco Mercador nunca figura Francisco de Baeza, y viceversa. Veáse por ejemplo las del año 1513 y parta de 1514, transcritas por Tristán García, Francisco, "Un patrimonio bastetano recuperado: las actas capitulares del Concejo de Baza (del 19 de agosto de 1513 al 18 de enero de 1514)".
} 
su análisis encontramos que, en términos absolutos, el uso del apellido Mercador es el preponderante, con el $65 \%$ de ocurrencias a lo largo de toda su vida (y también en los documentos del siglo XVI posteriores a su muerte), frente al $35 \%$ en las que utiliza Baeza, en este caso solamente durante la década indicada. Pero en determinados momentos este último apellido aparece con más abundancia, por ejemplo, durante los años 1508, 1511 y en el periodo 1513-1515, para descender progresivamente en los dos años sucesivos y desaparecer su uso definitivamente a partir de 1518; tal como se comprueba en la siguiente gráfica.

Uso de los apellidos Mercador y Baeza (1494-1520)

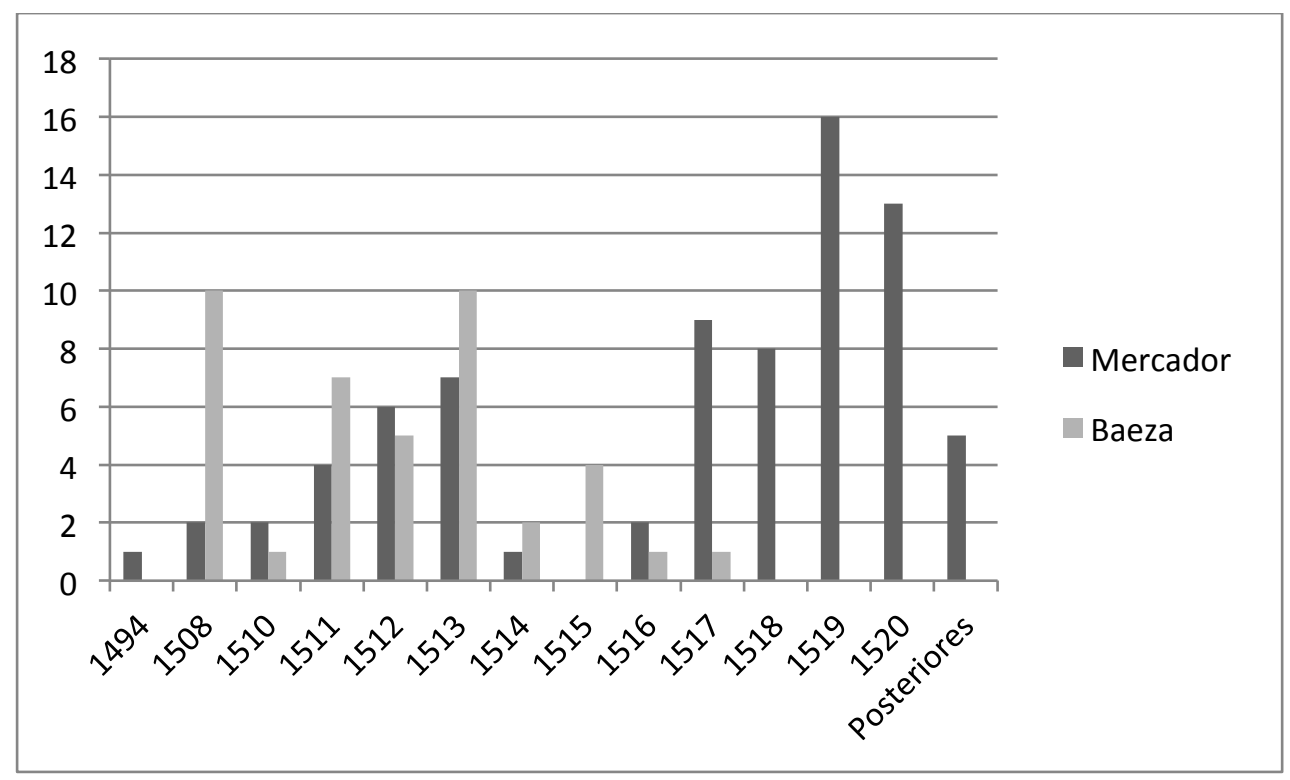

Lo sorprendente de este uso indistinto y al tiempo de dos patronímicos no es que se emplera por parte del propio personaje, cuando aparece como actuante (otorgante o testigo) en los documentos, sino que también se comprueba esta dualidad de uso cuando otras personas se referían a él. Pero es que, además, a lo largo de un mismo mes o semana aparecen ambos apellidos indiferentemente. Se ha podido localizar, incluso, un día concreto (el 14 de octubre de 1513) en el que en la sesión del cabildo de esa jornada se le denomina como el jurado Francisco Mercador mientras que también actúa como testigo en el otorgamiento de una escritura pública y firma como el jurado Francisco de Baeza. Y, reiteramos, que esta suerte de binomia no solo procede del sujeto que estudiamos, sino que tanto diversas instituciones (concejo de Baza, cancillería regia) como sus convecinos utilizaban también aleatoriamente ambos patronímicos para refererise a él. 
Qué sentido tiene este indistinto, prolongado y simultáneo uso de dos patronímicos es algo sobre lo que aún no tenemos una explicación plausible. Es sabido que durante la época medival y moderna en Castilla no existía un patrón único de uso de los patronímicos ni de los apellidos ${ }^{25}$. Como señala el profesor Soria Mesa:

"En ocasiones, las más, se seguía el identificador masculino; otras muchas se escogía el de la madre o el de una abuela; tampoco fue raro elegir el de un antepasado más remoto o incluso el de un colateral. Muy normal fue que los hermanos y hermanas se llamaran de forma muy diversa" ${ }^{26}$.

Y era habitual que, sobre todo en estamentos como la nobleza, un personaje a menudo figurase con unos nombres u otros a lo largo de su vida, en función de diversos motivos normalmente relacionadas con las estirpes de las que procedía y a las exigencias de los mayorazgos que podía disfrutar. Otra causa del cambio de apellidos solía ser la ocultacion de una ascendencia incómoda, normalmente por parte de perseguidos por la Inquisición o descendientes de estirpes humildes que habían logrado medrar en la escala social, pero no hemos encontrado referencias a un caso similar de simulteniedad en el uso de dos distintos patronímicos en las fuentes consultadas.

En cualquier caso, Francisco Mercador o de Baeza, fue un personaje conocido y relevante en la nueva sociedad fraguada tras la conquista de la ciudad de Baza. Como se ha comentado, no contamos con fuentes que nos permitan conocer su trayectoria durante el periodo a caballo entre los siglos XV y XVI, pero en 1508 encontramos ya a nuestro personaje -que por entonces se hacía llamar de forma preferente Francisco de Baeza- como mayordomo del concejo de Baza: un empleo municipal secundario y temporal, elegido bianualmente (en su caso para el periodo 1507-1508), pero de enorme transcendencia puesto que era el responsable de gestionar los ingresos y gastos del municipio ${ }^{27}$. Lo cual indicaría la experiencia de Mercador en asuntos económicos, así como una importante solvencia patrimonial, puesto que el mayordomo debía depositar una fianza al comienzo de su desempeño y, en ocasiones, hacer pagos por anticipado en nombre del concejo de su propio peculio. Esta debió ser su primera incursión en el concejo, pues no se conoce que hubiera ostentado otro cargo municipal, ni principal (regidor, alcalde ordinario) ni auxiliar, hasta ese momento.

\footnotetext{
25 "El hombre del Siglo de Oro, y me refiero sobre todo al hidalgo con pretensiones, escoge a su gusto entre los apellidos de sus mayores, y no se plantea duda al elegir el de una bisabuela si éste es más ilustre o sonoro que el de su padre". SAlazar y Acha, Jaime de, Génesis y evolución histórica del apellido en España, pp. 32-33.

26 Soria Mesa, Enrique, "Tomando nombres ajenos. La usurpación de apellidos como estrategia de ascenso social...,", p. 10.

27 Este cargo fue ostentado en el cabildo bastetano, de forma recurrente, por personajes de origen judeoconverso. CAstillo Fernández, Javier, “"Negocios de familia”: el perfil institucional y social de los mayordomos de propios del Reino de Granada (1492-1550)", pp. 41-42.
} 
Pero fue trascendental y oportunísimo para su trayectoria personal, pues sería precisamente en 1508 cuando, durante la segunda regencia de Fernando el Católico y en un contexto de inestabilidad política en Castilla, la mayor parte de los concejos de las ciudades del Reino de Granada modificaron radicalmente el método de selección de sus representantes municipales. Hasta entonces había estado vigente en la mayor parte de ellas -excepto en la capital- el conocido como "Fuero Nuevo" (concedido entre 1494 y 1495), que establecía una renovación bianual de los cargos concejiles. Pero aquel año se se asistió a un drástico proceso de patrimonialización de los principales puestos políticos: los de regidor y jurado -empleo este último no contemplado en el Fuero y que reaparecía de nuevo en estos concejos granadinos-, que pasaron a ser vitalicios por concesión regia. Todo ello en un intento del Rey Católico de atraerse a las élites locales ${ }^{28}$. En Baza, a partir de octubre de 1508, se fueron presentando ante el cabildo las reales provisiones de merced mediante las que se concedieron a determinados elementos de la oligarquía en ciernes un oficio de alférez mayor, diez de regidor y seis de jurados. Y fue, precisamente, Francisco de Baeza, mayordomo del concejo, el primero que presentó su credencial como flamante jurado perpetuo de la parroquia de Santa María (donde se incluía la medina y otros barrios principales de la ciudad), con un salario anual de 1.000 maravedíes, el 20 de octubre de ese año ${ }^{29}$. Al poco tiempo el concejo le encomendó asuntos de importancia, como un viaje a la Corte para obtener, en nombre de "la comunidad y universidad" de la ciudad, la confirmación de sus privilegios y mercedes por parte de la reina doña Juana ${ }^{30}$; confianza en este tipo de gestiones que se mantuvo y se reiteró posteriomente ${ }^{31}$. Pero su influencia política no se circunscribió a Baza, puesto que en mayo de 1513 obtuvo el cargo de regidor perpetuo de la cercana ciudad de Purchena ${ }^{32}$.

Francisco Mercador, perteneciente al escalón intermedio de la élite local y flamante jurado, tuvo un papel social, económico y militar relevante en la Baza de la época. En primer lugar, actuó asiduamente como testigo o en representación de otros vecinos en

\footnotetext{
28 Sigue siendo de gran utilidad, para estos aspectos, el trabajo de Ruız Povedano, José María, "Las élites de poder en las ciudades del reino de Granada".

29 La real provisión se había otorgado en Córdoba solo un día antes. AGS, RGS, 1508-10, fol. 6 y AMB, Libro de privilegios y provisiones, fol. 152 (al margen de la copia de esta real provisión concedida a Francisco de Baeza, el escribano del concejo anotó significativamente "Francisco Mercador"). Al parecer, aunque la legislación prohibía el ejercicio de dos empleos municipales de forma simultánea, se era más tolerante en las ciudades castellanas con el desempeño paralelo de los oficios de mayordomo y jurado. Corral García, E., El mayordomo de concejo en la corona de Castilla, p. 114.

30 Se le designó y dio poder para gestionar este y otros asuntos recogidos en un memorial. AMB, actas capitulares (en lo sucesivo, AACC), sesión de 1-XII-1508. El poder, en el acta de la sesión de 15-XII-1508. 31 A finales de 1518 se le encargó un viaje a la Corte para solicitar un juez de términos y fondos para concluir el puente sobre el río Barbata. Semanas más tarde presentaba ante el cabildo las reales provisiones obtenidas tras sus gestiones. AMB, AACC, sesiones de 5-XI y 13-XII-1518.

32 AGS, RGS, 1513-05, fol. 86. La Corona le concedió el oficio por renuncia de Alonso Doña (sin duda, el vecino de este nombre, también miembro de la oligarquía de Baza). No fue infrecuente que las élites granadinas ostentaran oficios sucesivos o simultáneos en los cabildos de distintas ciudades del reino. Véase Ruiz Povedano, José María, "Las élites de poder en las ciudades del reino de Granada”, pp. 384-385.
} 
numerosos contratos otorgados ante escribano público ${ }^{33}$, al igual que otras personas del estamento burgués que contaban con prestigio entre las clases medio-bajas, como los vecinos Pedro García de Mora, Andrés de Titos o Francisco Guillén (todos ellos, posteriormente, involucrados en la revuelta comunera). Al mismo tiempo, mantuvo una destacada actividad económica: negocios de ganado ${ }^{34}$, adquisición ${ }^{35} \mathrm{y}_{\text {venta de fincas }}^{36}$, cesión de las mismas mediante arrendamiento ${ }^{37} \mathrm{o}$ a censo perpetuo ${ }^{38} \ldots$ Por aquellos años también se deshizo de algunas propiedades que poseía en Cazorla, como unas casas en el barrio de la Matea ${ }^{39} \mathrm{y}$ adquirió otras fincas en Purchena ${ }^{40}$. Tampoco rehusó el pingüe negocio de la gestión de impuestos. En 1508 fue receptor de las rentas reales de Baza y su partido ${ }^{41}$ y años más tarde, junto a otros socios, se hizo con la recaudación de la renta del Voto de Santiago en la zona durante seis años ${ }^{42}$.

Otro ámbito donde Francisco Mercador continuó destacando a lo largo de su vida fue en el militar. El final de la Guerra de Granada no supuso el de su trayectoria castrense. Y es que, como otros antiguos "fronteros", su experiencia y concurrencia resultó muy útil tanto para la defensa del reino granadino como para las empresas del Norte de África puestas en marcha por la Corona de Castilla. Así, en un memorial de 1506 que proponía los medios para la conquista de Orán (expugnada, como es sabido, tres años

\footnotetext{
33 Resulta frecuente que actuara y firmara como testigo en nombre de vecinos analfabetos, en algunos casos miembros de la minoría morisca de la ciudad y su tierra. Algunos ejemplos, en los protocolos bastetanos, en Archivo Histórico del Colegio Notarial de Andalucía, sede de Granada, Distrito de Baza (en adelante AHCNA-G, Baza), Prot. 1, fol. 13 (año 1510), Prot. 2, fol.293 (año 1512), Prot. 3, fol. 404 (año 1515) o Prot. 7, fol. 13 (año 1518) y fol. 358v (año 1519).

34 Nuestro jurado parece que se especializó en la compra y venta de cerdas de cría. Véase, por ejemplo, AHCNA-G, Baza, Prot. 2, fol. 380 y Prot. 7, fols. 361 y 361v. Las regestas de las escrituras de la escribanía más antigua conservada, la de Diego de Ahedo, se pueden consultar en la tesis doctoral de CRESPO Muñoz, Francisco Javier, El notariado en Baza (Granada) a comienzos de la Edad Moderna: estudio y catálogo de los protocolos notariales (1510-1519).

35 Compra de dos bancales en el pago del Lomo por 8.624 maravedíes (AHCNA-G, Baza, Prot. 1, fol. 38). Adquisición de una casa en la parroquia de Santiago por 21.000 maravedíes (Ibidem, Prot. 7, fol. 140v).

36 Venta de un predio de riego en el pago de las Fontecillas por 3.200 maravedíe. Ibidem, fol. 73.

37 Arrendamientos de una heredad de tierras y viñas en el pago de Zoaime (Ibidem, Prot. 2, fol. 291); de un finca de viñas y tierras de cultivo en el de paraje de Zalema (Ibidem, Prot. 2, fol. 393) y de tres bancales con árboles en la Carrera (Ibidem, Prot. 5, fol. 192).

38 Cesión de un bancal con árboles en el camino de Freila (Ibidem, Prot. 2, fol. 505). En agosto de 1517 autorizó el traspaso de una vivienda suya, situada en el barrio de San Juan o "Morería", cargada con un censo perpetuo anual de 4 reales y 6 maravedíes (Ibidem, Prot. 5, fol. 155v). Cesión a censo enfitécutico de la viña y bancales de Zoaime (Ibidem, fol. 448).

39 Vendidas a un vecino de esa localidad en 8.000 maravedíes, en noviembre de 1512. Ibidem, Prot. 3, fols. 316 y 317. Véase apéndice documental 2.

40 Archivo del Marqués de la Hermida, Granada (en adelante AMdLH), traslado de una escritura de 13 de diciembre de 1517 en la que Diego Róquez, escribano del marqués de los Vélez, vende una huerta en el pago del Quenze, de Purchena, a Francisco Mercador, regidor de la ciudad.

${ }_{41}$ AGS, RGS, 1510-12, fol. 585.

42 Creó una compañía junto a dos socios, Antonio Pérez y Cristóbal Guerrero, para hacerse con la renta de los partidos de Baza y de Purchena, en mayo de 1520 (AHCNA-G, Baza, Prot. 12, fol. 752). Al final consiguieron, al menos, los votos del partido compuesto por la tierra y hoya de Baza, la de Huéscar, la de los Vélez, Orce, Galera, Castril y Cortes para el periodo 1520-1526 (Ibidem, Prot. 8, fol. 208v).
} 
más tarde), se afirmaba que entre las tropas expedicionarias "son menester tresientos onbres del campo de la frontera del Reyno de Granada, que se avrán muy buenos"43. Y, en la preparación de la definitiva campaña para su conquista, financiada por el propio regente cardenal Cisneros (y en la que tuvo, asimismo, una notable participación en armas y hombres el Adelantamiento de Cazorla, perteneciente al arzobispo toledano y gobernado entonces por su sobrino García de Villarroel), se hacía hincapié en la necesidad de "buenos capitanes, esforçados, esperimentados, que tengan más fin a su honrra que no al ynterese, asy para la gente de caballo como para la de pie"44. Y quién mejor para esta empresa que los veteranos de la guerra granadina, como recomendaba expresamente el famoso Fernán Pérez del Pulgar, "el de las Hazañas", en una misiva escrita en su retiro de El Salar (Loja) en abril de 1509 al conde Pedro Navarro, responsable militar de la expedición a Orán:

“Acá, señor, se reza de la guerra quel Rey nuestro señor manda fazer a los moros de África. Paso a suplicar a vuestra señoría, al tiempo que se fizieren nóminas de la gente que en buena ora han de pasar a África, no se le olvide de mandar buscar y poner en ellas los más adalides y onbres del campo que se pudieren aver. En espeçial de aquellos que siguieron la guerra pasada deste reyno de Granada. Porque éstos, como quier que los moros son astutos en la guerra y diligentes en ella, los que han sido en guerrear los conosçen bien y saben armalles"45.

Y a pesar de que en estas campañas la mayoría de la recluta procedía de fuera del Reino de Granada (puesto que nunca se quiso dejar vacío este de tropas y milicias locales, ante el recelo que levantaba su importante comunidad morisca), siempre hubo un pequeño contingente de la zona. Así, por ejemplo, cuando por esas fechas se planeaba una expedición para asegurar Cazaza y conquistar Vélez de la Gomera, entre los 9.000 hombres que se consideraba necesario reclutar, procedentes en su mayor parte del resto de Andalucía, figuraba una veintena de escuderos a pie de Baza, así como otros pequeños contingentes de otras ciudades granadinas ${ }^{46}$. También conviene recordar que entre las competencias de los jurados de muchas ciudades castellanas se encontraba las de organizar la defensa de su parroquia o collación (guarda de puertas, rondas nocturnas) ${ }^{47}$,

\footnotetext{
43 Arhivo Histórico Nacional (en adelante AHN), Universidades, libro 730, s. fol. En un borrador que se encuentra en el mismo volumen, posiblemente del mismo año, se habla expresamente del envío de "dosyentos honbres del canpo de Caçorla y Quesada y de aquella frontera".

44 Ibidem. "Memorial de Hernando de Çafra, de la gente que es menester para passar en allende y asymesmo de los bastimentos". El veterano secretario real, curtido en la Guerra de Granada y en la posterior organización del reino conquistado, recogía en este informe atinadas consideraciones sobre cómo debían ser y actuar los oficiales y el resto del personal de la expedición.

45 Carriazo Arroquia, Juan de Mata, "La vida en la frontera de Granada", p. 281. El texto de la carta continua describiendo, en detalle, las distintas habilidades de estos adalides en el campo de batalla.

46 AHN, Universidades, libro 730, s. fol. "Memorial de Hernando de Çafra...".

47 Aranda Pérez, Francisco José, Poder municipal y cabildo de jurados en Toledo en la Edad Moderna, p. 66 .
} 
elaborar listas de vecinos y armas y organizar el reclutamiento de los mismos en caso de necesidad: por ejemplo, y para el caso bastetano, en los frecuentes socorros a alguna localidad costera cuando era amenazada por los corsarios norteafricanos.

Lo cierto es que el jurado Mercador nunca se desvinculó de la milicia y, durante aquellos años, estuvo al frente de una unidad de infantería en el Norte de África, tal como se recordaba poco después en un documento regio: "ha servido como capitán de la gente de infantería en las guerras de África, así en Mazalquivir como en la ciudad

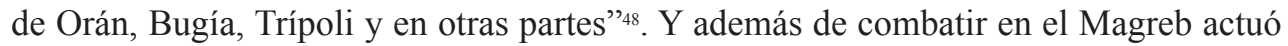
como oficial reclutador en la Península, con patente del alcaide de los Donceles, capitán general de Tremecén. En efecto, el 11 de junio de 1511 don Diego Fernández de Córdoba otorgaba en Orán poder y facultad al jurado Francisco de Baeza para reclutar doscientos hombres en Castilla, con el objeto de conducirlos a esa plaza norteafricana ${ }^{49}$, para lo cual le autorizaba a nombrar sendos capitanes que estuvieran al frente, cada uno de ellos, de un centenar de soldados. El jurado bastetano consiguió alistar, solo en Baza, a más de medio centenar de voluntarios, pero pronto surgieron problemas al no recibir la paga que les correspondía "dende el día que asentamos en su capitanía para yr a Orán hasta dya de la fecha"so. Mientras esto sucedía, el flamante reclutador no permanecía inactivo, nombrando a su convecino Lope de Saravia como uno de los dos capitanes del contingente que se estaba reclutando y designando a Lorenzo Ballester como su lugarteniente ${ }^{51}$.

Todo indica que debió sentirse muy orgulloso de este empleo, pues durante ese periodo lo encontramos autotitulándose, y firmando, como "el capitán Francisco de Baeza" en todo tipo de documentos. Pero, su más que probable carácter violento ${ }^{52}$ y una rigurosa aplicación de la disciplina militar en los presidios africanos le granjeó la enemistad de algunos de sus subordinados, por lo que en 1513 solicitó a la Corona licencia de armas defensivas para él y dos acompañantes, pues "teniendo cargo de la dicha gente ha castigado a algunas personas por sus yerros, y por ello se teme y recela que las dichas personas le querrán herir o matar, o hacer otros daños en su persona"s3. En todo caso, una vez concluidas las campañas norteafricanas mantuvo su estatus militar como

\footnotetext{
48 AGS, RGS, 1513-09, fol. 353.

49 La ciudad argelina mantenía una guarnición de en torno a 2.000 soldados en mayo de 1510 y de algo menos de 1.800 en junio de 1512. Gutiérrez Cruz, Rafael y Martín Palma, María Teresa, "Documentos para el estudio de la población de Orán y Mazalquivir tras la conquista”, pp. 253-254.

50 Baza, 6 de julio de 1511. Poder otorgado por un grupo de vecinos y estantes en Baza a Cebrián Gómez para que en el nombre de todos cobrase del jurado Francisco Mercador el sueldo que se les debía. AHCNAG, Baza, Prot. 1, fol. 307.

${ }_{51}$ Las dos cartas de poder se otorgaron en Baza el 14 de julio de ese año. Ibidem, fols. $317 \mathrm{v}$ y $318 \mathrm{v}$.

52 Véase el apartado 3 de este trabajo.

53 AGS, RGS, 1513-09, fol. 353.
} 
caballero de acostamiento de la Corona ${ }^{54}$ e intercedió en nombre de otros en la Corte en asuntos de esta ${ }^{55} \mathrm{y}$ otra naturaleza, tanto privados como comunitarios ${ }^{56}$.

Es posible que este asiduo contacto con el Consejo Real le facilitara la obtención de nuevas recompesas por sus antiguos servicios militares en la conquista granadina. De este modo el 4 de enero de 1511 nuestro jurado consiguió sendas e importantes mercedes: por un lado la concesión del privilegio de ostentar escudo de armas, en el que figurasen dos castillos en recuerdo de los dos desafíos vencidos a los enemigos durante el cerco de Baza (véase su transcripción en el apéndice documental 4)57; por el otro, la confirmación regia de la licencia municipal para construir una venta para caminantes en el término de la antigua alquería y castillo nazarí de El Baúl, en el camino real entre Baza y Guadix ("en un cortyjo que está caydo en el dicho camino, donde diz que en tiempo de los moros estaba una torre"), en renumeración a su entrega en la guerra de Granada, donde resultó cautivo ${ }^{58}$. La primera merced confirmaba y acrecentaba su condición nobiliaria y la segunda, además de incrementar su patrimonio, le daba opción a crear un gran heredamiento, quien sabe si con pretensiones pseudoseñoriales.

El heredamiento de El Baúl había sido solicitado a los Reyes Católicos para erigir una venta por parte de su su contino Gonzalo Núñez ${ }^{59}$. En mayo de 1494 los monarcas ordenaron al concejo de Baza que no impidisen al criado real plantar árboles, viñas y sembrar en las cuarenta fanegadas de tierra concedidas ${ }^{60}$ y esta orden se completó al poco con una franqueza de impuestos, reales y municipales, a los que habitaran en el heredamiento y venta, así como sobre los mantenimientos que se vendieran allí para los caminantes ${ }^{61}$. Desconocemos qué ocurrió con la propiedad de Núñez, pero lo cierto es que, como se ha indicado, el concejo de Baza la cedió en torno a 1510 al jurado Mercador para erigir una nueva venta, justo al lado de una zona de sierra donde se había establecido una dehesa concejil: "en el castillo de El Baúl, con el pensamiento de que en un monte que allí hay se criasen carrascas y caza”. Este adehesamiento, según

\footnotetext{
54 El 6 de enero de 1517 el jurado Francisco de Baeza, en su nombre y en el de otros cinco vecinos de Baza, otorga poder para demandar el sueldo del acostamiento de 1515 que se les debía. AHCNA-G, Baza, Prot. 5, fol. 716v.

55 En julio de 1513 su convecino Gonzalo de Molina le otorgó poder para que gestionase su renuncia a servir en la compañía del conde de Alba de Liste y para encuadrarse como escudero de acostamiento de Su Majestad. IBIDEM, Prot. 2, fol. 731.

56 En 1514 encabezaría una petición en nombre de los propietarios de palomares de Baza. AGS, RGS, 1514-09, fol. 233.

57 IBIDEM, fol. 113. En el documento se le denomina como Francisco Mercador y aparece como vecino de Cazorla.

58 IBIDEM, 1511-01, fol. 78. Merced a Francisco de Baeza, vecino y jurado de Baza, para edificar una venta en el camino de El Baúl, término de esa ciudad.

59 Merced otorgada en Barcelona, a 20 de noviembre de 1492. El 14 de febrero del año siguiente Gonzalo de Cortinas, repartidor de Baza, daba posesión a Núñez de 35 fanegas de tierra y monte donde levantar la mencionada hospedería. AMB, LRB, fol. 87.

60 Medina del Campo, 2-V-1494. AGS, RGS, 1494-5, fol. 40 y Escribanía Mayor de Rentas, leg. 35 (antiguo 55), fols. 537-538.

${ }_{61}$ Medina del Campo, 19-VI-149. AGS, Escribanía Mayor de Rentas, Mercedes y Privilegios, leg. 15, fol. 46 .
} 
Mercador, resultaba inútil pues "la tierra es tan estéril que el monte nunca más creció ni se ha criado caza" y solo servía para multar a los vecinos que acudían a cazar y a cortar leña. Así que, en el verano de 1513, encabezó de nuevo una petición popular para que la Corona deshiciese dicha redonda ${ }^{62}$, seguramente con el inconfesado deseo de ampliar de forma subrepticia su heredamiento y de reconstruir el antiguo hisn nazarí como una suerte de "casa fuerte" pseudoseñorial que lo dominara. Así parece indicarlo el acuerdo que el ayuntamiento de Baza tomó en diciembre de ese año:

"Este día sus merçedes mandaron notificar a Francisco Mercador que no edifique el castillo del Baúl so pena de cien quarenta mil maravedíes para la cámara de $\mathrm{Su}$ Alteza tanto que muestre el tytulo con qué lo hace" ${ }^{63}$.

Toda esta trayectoria ascendente de acumulación de mercedes, honores, oficios y propiedades le permitió consolidar un estatus social preheminente en la ciudad de Baza, como denotan otros signos externos de distinción, tales como la posesión de criados y esclavos $^{64}$, la dotación de obras pías ${ }^{65}$ o la erección de una capilla para enterramiento familiar en la Iglesia Mayor de la ciudad. Abundaremos más en este aspecto en el análisis de su testamento, que se realiza en el apartado 3.

\section{Su participación en la efímera revuelta comunera en Baza (agosto de 1520)}

La producción historiográfica sobre las Comunidades de Castilla resulta amplísima y, además de los clásicos decimonónicos ${ }^{66} \mathrm{y}$ de finales del siglo $\mathrm{XX}^{67}$, no ha dejado de crecer en las últimas décadas, diversificando además sus ámbitos de análisis desde múltiples

\footnotetext{
62 AGS, RGS, 1513-09, fol. 167.

63 Tristán García, Francisco, "Un patrimonio bastetano recuperado: las actas capitulares del Concejo de Baza...,, p. 356.

64 A uno de sus criados, Pedro Gómez de Segura, lo encontramos identificado como tal en escrituras de 1515 (AHCNA-G, Baza, Prot. 3, fols. 319v y 352), mientras que en su testamento se cita a una criada, con la que tuvo un hijo bastardo. Asimismo, sabemos que contaba al menos con una esclava, llamada María Mercador, de raza nega (Ibidem, Prot. 51, año 1562, fol. 456).

65 Mercador era patrón de un conjunto de bienes inmuebles que donó a las Ánimas del Purgatorio. Ibidem, Prot. 4 (1516), fol. $127 \mathrm{v}$.

${ }^{66}$ La obra más conocida y citada sigue siendo el estudio y compilación documental debidos a DANVILA y Collado, Manuel, Historia crítica y documentada de las Comunidades de Castilla.

${ }^{67}$ Las principales monografías, por orden de aparición, fueron las de Maravall, José Antonio, Las Comunidades de Castilla: una primera revolución moderna (1963), Gutiérrez Nieto, Juan Ignacio, Las comunidades como movimiento antiseñorial (1973), PÉrez, Joseph, La revolución de las Comunidades de Castilla (1977) y Haliczer, Stephen, Los comuneros de Castilla. La forja de una revolución (1987), a las que cabría añadir, ya a comienzos de la presente centuria, la debida a Diago HeRnANDo, Máximo, Le Comunidades de Castiglia (1520-1521). Una rivolta urbana contro la monarchia degli Asburgo (2001).
} 
puntos de vista (políticos, sociales, económicos, ideológicos, locales y regionales...) ${ }^{68}$. No es este el lugar para siquiera apuntar el alcance, impacto y desarrollo de la revuelta, y la oposición a la misma, en los reinos que componían la Corona de Castilla, y que hundía sus raíces en la confusión política y el descontento social que se venía gestando desde, al menos, la muerte de la reina Isabel la Católica.

La fugaz sublevación comunera ocurrida en Baza, "la primera ciudad que se alzó en Granada, y en toda Andalucía, a favor de las Comunidades", ya ha sido estudiada con cierto detalle y calificada como "un temprano levantamiento antioligárquico y revolucionario" 69 , que se ha demostrado estaba perfectamente incardinada y conectada con la rebelión general de Castilla y con otras comunidades más cercanas, como las del Reino de Murcia. Como en otros muchos lugares del reino, la revuelta bastetana fue la espita que estalló tras años de acumulación a nivel local de agravios en determinadas capas sociales, en un contexto de descontento popular provocado por el fracaso de los presupuestos de la repoblación acometida apenas treinta años antes y ante la progresiva oligarquización de los resortes del poder ciudadano y la creciente presión fiscal.

La ciudad de Baza, aunque de realengo, estaba controlada desde fines de siglo XV por la familia de los Enríquez de Guzmán y Luna, del linaje de los almirantes de Castilla y emparentados directamente con la familia real, puesto que don Enrique Enríquez era tío materno de Fernando el Católico. Beneficiaria de cuantiosas mercedes en el reparto de la ciudad tras la conquista ${ }^{70}$, controlaba a través de su clientela el cabildo de la ciudad, además de ostentar las tenencias de las principales fortalezas de la comarca y de beneficiarse de cuantiosos situados sobre las rentas reales del partido de la ciudad. Por si esto fuera poco, los señoríos granadinos de esta casa rodeaban a la propia Tierra de Baza, tanto en su ámbito granadino -Orce, Galera y Cortes- como almeriense -Sierra de Filabres- En los años previos al estallido comunero existieron numerosos pleitos de términos entre la ciudad de Baza y algunos de estos lugares de doña María de Luna, viuda de don Enrique Enríquez ${ }^{71}$. No es de extrañar que el cronista Alonso de Santa Cruz apuntase como causa para que los bastetanos se levantaran el que

“decían que doña María de Luna, mujer que fue de don Enrique, los tenía allí opresos, siendo ellos del Rey, y que los hijos tenían la fortaleza y ella se metía en

\footnotetext{
${ }_{68}$ Un estado de la cuestión, relativamente reciente, de las principales casuísticas e interpretaciones en torno al fenómeno se puede ver en el trabajo de Alonso García, David, "Las Comunidades de Castilla en el s. XXI".

69 Véase Castillo Fernández, Javier, "Conflictos y protestas populares en el reino de Granada (15041521)" y "La rebelión de las Comunidades en el Reino de Granada: los casos de Huéscar y Baza". La cita es de este último trabajo, p. 25.

70 Casi el $10 \%$ de las tierras repartidas en la localidad fueron a parar a sus manos; sin contar las adquisiciones privadas y las mercedes del concejo en años posteriores. TRISTÁN GARCíA, Francisco, "Enrique Enríquez, el primer repoblador de los Reyes Católicos".

71 Una relación de parte de ellos se puede ver en AMB, AACC, sesión de 8-X-1518.
} 
los términos y que los nietos les tomaban las posadas y les disfamaban las hijas, y que por estas cosas determinaban antes morir libres que no vivir como esclavos"72.

Aparte de estos agravios históricos, uno de los desencadenantes directos de la revuelta, como en otros sitios de Castilla, fue el espinoso asunto del encabezamiento de las rentas reales, que los comuneros enarbolarían como bandera ${ }^{73}$. En el caso de Baza, aunque un grupo de mercaderes y artesanos había negociado y conseguido encabezar las rentas -un sistema de recaudación más beneficioso para el común- con la Corona, el concejo se empeñó en arrendarlas a un especulador de origen forastero a finales de julio ${ }^{74}$. Cuando los ediles, comprobando que la situación se les iba de las manos, intentaron echar marcha atrás ya era demasiado tarde ${ }^{75}$.

Determinados elementos destacados de la burguesía local -los denominados "hombres buenos" o "populares"- catalizaron este descontento contra los miembros del concejo y contra la familia de los Enríquez-Luna, organizándose como una "comunidad" defensora del bien común. La caracterización de los líderes rebeldes es bastante ilustrativa del carácter del movimiento bastetano: casi todos eran mercaderes, artesanos, labradores y medianos propietarios de ganado, mayoritariamente vecinos del arrabal de Santiago, el barrio extramuros donde residían las clases populares de origen cristianoviejo; es decir, los antiguos peones del repartimiento, aquellos que habían sufrido más el desencanto de la repoblación y las prevaricaciones del concejo. La población de esta parroquia contrastaba con la de la medina amurallada, núcleo de la parroquia de Santa María, donde residían las clases más acomodadas, o la de San Juan o "Morería", donde habitaba la mayor parte de la minoría morisca.

Sin embargo, también encontramos involucadros en la revuelta comunera a algunos miembros del concejo, como al regidor Juan de Araoz, un acaudalado y antiguo deudo de los Enríquez que había roto con ellos por diversos agravios recibidos ${ }^{76}$, a los dos únicos jurados que no eran clientes de los Enríquez-Luna (el propio Mercador y el representante de la parroquia de Santiago, Andrés Henández de las Navas), así como al personero y procurador síndico de la ciudad, "y de la Comunidad della", Cristóbal de Ayvar, al teniente de escribano de concejo Per Álvarez y al que había sido alcalde mayor hasta mayo de 1519: el doctor o licenciado Diego Martínez de Burgos ${ }^{77}$.

Las inclinaciones políticas de Francisco Mercador no resultan fáciles de determinar. Jurado de Santa María, no de la parroquia de Santiago - núcleo de la revuelta-, algunas

\footnotetext{
2 Santa Cruz, Alonso de, Crónica de Carlos V, vol. I, p. 370.

73 Pérez, Joseph, La revolución de las Comunidades, p. 551.

AMB, AACC, sesión de 27-VII-1520.

AMB, AACC, sesión de 8-VIII-1520.

76 CAstillo FernÁndez, Javier, "El origen del concejo y la formación de la oligarquía ciudadana en Baza", p. 67.

77 Se había caracterizado por su apoyo a las clases populares y por el inusual hecho de que, tras cesar en su cargo, en lugar de marcharse -como era habitual en estos oficiales temporales designados por el corregidor de turno- había decidido avecindarse en la ciudad.
} 
de sus actuaciones en el concejo no parecían ir en la línea pro-comunera: a comienzos de 1519 se opuso a que se cubriera el cargo de personero y procurador del común ${ }^{78}$ y a mediados de julio de 1520, cuando el ambiente prerrevolucionario debía ser evidente en Baza, denunció y solicitó al corregidor que investigase porqué algunos vecinos se habían incluido falsamente en las peticiones y poderes con los que Juan Guillén -que al poco sería elegido como uno de los síndicos de la Comunidad-y consortes habían conseguido de la Corona una real provisión en contra de que se arrendasen las alcabalas y a favor del encabezamiento por parte de los mercaderes y ganaderos de la ciudad $^{79}$. Sin embargo, es bastante sintomático que fuera uno de los pocos miembros del cabildo que no estaba adscrito a la casa de los Enríquez y, también, que en marzo de 1519 encabezara a un nutrido grupo de vecinos de la localidad que, "en nombre de la Comunidad", propugnaban la apertura de una nueva puerta en la muralla de la medina para comunicarla con el popular arrabal de Santiago, a lo que se oponía el alcaide de la alcazaba, don Enrique Enríquez II, nieto de doña María de Luna, y sus paniaguados ${ }^{80}$. En cualquier caso, su experiencia militar y su fuerte personalidad debió ser determinante a la hora de ser elegido como capitán y líder militar de los rebeldes, pues la mayoría de las fuentes conocidas lo caracterizan como la cabeza visible de la sublevación en Baza. El coetáneo cronista Alonso de Santa Cruz afirmaba: "fue el que levantó aquella ciudad un Francisco Mercader (sic), pobre escudero" "81; mientras que el marqués de Mondéjar lo identificaba como "capitán de su Germanía"\$2. Lo cierto es que a comienzos de agosto ${ }^{83}$ se produciría el airado levantamiento de la mayor parte de los vecinos de Baza. Los sublevados se dirigieron a la residencia del alcalde mayor, licenciado Diego Delgadillo, al que tomaron y quebraron la vara de justicia, nombrando en su lugar a dos alcaldes. Ante el tumulto popular, los regidores que estaban celebrando su reunión capitular se refugiaron con sus familias y otros vecinos en la fortaleza, al amparo de su alcaide don Enrique Enríquez II ${ }^{84}$.

Una vez con el control de la ciudad, se constituyó la Comunidad de Baza, a cuya cabeza se situó el capitán Mercador, dos alcaldes y varios síndicos elegidos de entre

\footnotetext{
78 En esta petición le secundaron otros dos jurados. AMB, AACC, sesión de 2-I-1519.

79 AMB, AACC, sesión de 18-VII-1520. En el cabildo celebrado dos días antes se le había designado para que marchase a la Corte, a petición de Diego de Castro, arrendador de las alcabalas de la ciudad, para que aclarase con los contadores mayores a quién correspondía la recaudación del impuesto, puesto que Juan Guillén y sus socios, mercaderes locales, habían obtenido una real provisión que les facultaba para lo mismo. No parece que este viaje tuviera lugar pues asistió a la sesión de 27 de julio donde el concejo, finalmente, a petición del personero que hablaba en nombre de la "comunidad, vecinos y universidad" de la ciudad, decidió apoyar que el encabezamiento lo gestioran los comerciantes locales.

80 AGS, Cámara de Castilla, leg. 132-31.

81 Santa Cruz, Alonso de, Crónica de Carlos V, vol. I, p. 370

82 Carta de Mondéjar al emperador relatando lo sucedido en Baza (Alhambra, 11-9-1520). DANVILA Y Collado, Manuel, Historia crítica y documentada de las Comunidades de Castilla, t. 2, pp. 165-168.

83 El día 2, según Santa Cruz, a mediados de mes, según Juan Ignacio Gutiérrez Nieto, Las comunidades como movimiento antiseñorial, p. 211. No se conserva documentación municipal sobre la revuelta. El concejo "leal" no se reunió entre el 8 de agosto y el 7 de septiembre de 1520.

${ }^{84}$ Magaña Visbal, Luis, Baza histórica, p. 379.
} 
los vecinos de mayor prestigio ${ }^{85}$, a imagen del modelo adoptado por los comuneros murcianos $^{86}$, debido a la estrecha relación y dependencia con el movimiento de aquel reino $^{87}$. Al parecer -como revela la misiva que transcribimos en el apéndice documental 3- la intención de los bastetanos era constituir una "Hermandad" de autodefensa con la ciudad de Lorca, al otro lado de la antigua frontera, a la que se dirigió en petición de ayuda. Sin embargo, la existencia de numerosa población morisca en la comarca sublevada hizo que el apoyo lorquino se matizara y que los comuneros de esta ciudad murciana aconsejasen a los de Baza que se sosegasen, ofreciéndoles incluso apoyo militar para este aplacamiento, si fuera necesario.

Tras tomar conciencia del alcance de la sublevación de Baza, el 19 de agosto el corregidor don Pedro de Acuña, tras solicitar ayuda al capitán general del reino, partió desde la ciudad de Guadix para tratar de aplacar la revuelta. A su llegada los rebeldes le habrían conminado a unirse a la Comunidad, pero ante su negativa "le quisieron matar e vinieron con atanbor y vanderas fasta su posada". Avisado a tiempo por doña María de Luna, se refugió asimismo en la fortaleza ${ }^{88}$. Los comuneros, por intervención del capitán Mercador, consiguieron traer alguna artillería de la fortaleza de Mojácar para batir la alcazaba, "redujeron a ruinas las viviendas de los caballeros más significados por su adhesión a la causa del Rey" ${ }^{89}$ y se aprestaron a la fortificación y defensa de la ciudad.

Mientras, en Granada, el marqués de Mondéjar consiguió en tiempo récord movilizar un importante y heterogéneo ejército, compuesto por tropas regulares, milicias populares, nobles y moriscos armados al efecto, que salió de Granada el 19 de agosto. Expedición a la que se unirían tropas de Guadix y del señorío de Gor y un contingente jienense comandado por don Diego de Carvajal, señor de Jódar ${ }^{90}$. En total, un mínimo de 2.500 hombres. Tras su entrada en Baza llegarían otros 400 peones enviados por el corregidor de Úbeda y Baeza. No parece que los rebeldes presentasen resistencia pues ante la llegada del ejército leal buena parte de los insurgentes huyó a Lorca y a otras comarcas cercanas, lo que fue aprovechado por los cercados en la alcazaba, que contraatacaron y se hicieron con el control de la ciudad, apresando a bastantes insurgentes ${ }^{91}$. Según se encargarían de des-

\footnotetext{
85 El 19 de agosto el personero del concejo, Cristóbal de Ayvar, traspasó sus poderes a Andrés Hernández de Titos, Pedro García de Mora, Juan Guillén, Francisco Guillén y Tomás de Cazorla, ciudadanos de reconocido prestigio entre el vecindario bastetano. AHCNA-G, Baza, Prot. 8, fol. 358.

${ }^{86}$ Owens, J. B., Rebelión, monarquía y oligarquía murciana en la época de Carlos $V$, p. 85 y 94 . En Murcia había once síndicos de representación parroquial y un capitán. Lorca tenía doce síndicos, capitán, alférez y otros cargos. Jiménez AlCÁzAr, Juan Francisco, Un concejo de Castilla en la frontera de Granada: Lorca 1460-1521, p. 472.

87 Lorca estaba en rebeldía desde el 20 de junio. Murcia se había unido a la Comunidad el 17 de mayo, pero no se constituiría como un poder popular hasta el mes de agosto. Véase Hernández Franco, Juan y Jiménez AlcÁzar, Juan Francisco, "Estado, aristocracia y oligarquías urbanas en el reino de Murcia. Un punto de flexión en torno a las Comunidades de Castilla”.

88 AGS, Consejo Real, leg. 495-3.

89 Magaña Visbal, Luis, Baza histórica, p. 370.

90 Carta del emperador agradeciéndole este servicio (Maastrich, 15-X-1520). Real Academia de la Historia, colección Salazar y Castro (en adelante RAH, SyC), 9-934, fols. 48v-49r.

91 AGS, Consejo Real, leg. 495-3 y AMB, AACC, sesión de 18-XI-1520.
} 
tacar los partidarios del corregidor Acuña, gracias a la intercesión de éste no se produjo el saqueo y destrucción de la ciudad que, en opinión de aquellos, Mondéjar deseaba. Es importante destacar que el aquietamiento militar de la Comunidad bastetana, que se debió producir a lo largo de la última semana de agosto ${ }^{92}$ y que atemorizó y sosegó, al menos temporalmente, otros conatos del entorno (como los de Huéscar y Cazorla), tuvo lugar pocos días despúes del incendio de Medina del Campo por parte de las tropas realistas (21 de agosto), acción que provocó la radicalización y extensión de la rebelión comunera por buena parte de Castilla.

Tras la entrada en Baza del ejército comandado por don Luis Hurtado de Mendoza se procedió durante los días siguientes a la detención de más de cincuenta comuneros. Según sus propias palabras:

"procuré de prender de los culpados que andaban heridos los más que puede. Y entrellos acertó a ser preso el capitán de su Germanía, que era un Francisco Mercador, jurado de aquella cibdad. Y a este hice degollar" ${ }^{93}$.

En efecto, el jurado y capitán de la Comunidad de Baza, tras ser sometido a un proceso sumario por parte del alcaide Lázaro de Peralta, alcalde mayor de la gente de guerra del Reino de Granada ${ }^{94}$, fue condenado a muerte y ejecutado. Debido a su consideración hidalga ${ }^{95}$ sería degollado y, según el cronista Santa Cruz, descuartizado ${ }^{96}$, con el claro objetivo de servir de escarmiento y de ejemplo a la otrora rebelde población. La ejecución tuvo lugar el día 31 de agosto de 1520 o poco después. Por lo tanto, Mercador fue uno de los primeros líderes comuneros ejecutados en toda Castilla y, desde luego, el primero de Andalucía y en todos los territorios castellanos al sur del Tajo ${ }^{97}$.

\footnotetext{
92 La entrada se produjo algún día después del 25 -fecha de la carta de la Comunidad de Lorca, que estaba en poder de Mercador-y, desde luego, antes del 31 -día en que este otorgó testamento-

93 Carta de Mondéjar al emperador (Granada, 11-IX-1520). Danvila y Collado, Manuel, Historia crítica y documentada de las Comunidades de Castilla, t. 2, pp. 165-168. Estos heridos serían, probablemente, los que no habían podido huir.

94 Peralta era uno de los principales criados y "agentes" de los Mendoza, tanto en el aparato militar del Reino de Granada como en el cabildo de la capital. Fue alguacil, alcaide y alcalde de la gente de guerra, receptor y pagador del sistema fiscal y de vigilancia de la costa, en el partido del arzobispado de Granada (hasta julio 1508) y alférez de la compañía de las cien lanzas jinetas de las Guardias Viejas de Castilla adscrita a la capitanía general (1513). También fue jurado (1512-1516) y regidor del ayuntamiento granadino (1516-1520), donde defendió los intereses de sus señores. JimÉnez Estrella, Antonio, Poder, ejército y gobierno en el siglo XVI: la Capitanía General del Reino de Granada y sus agentes, pp. 289 y 332. Agradezco al profesor Jiménez Estrella esta información.

95 Las Partidas establecían que "los nobles eran degollados o empozados; y en caso de ser degollados no valía cualquier arma blanca o utensilio, debía ejecutarse con espada o cuchillo, pero no "con segur nin coz de segar"”. BAZÁn, Iñaki, "La pena de muerte en la Corona de Castilla en la Edad Media”, p. 318.

96 Santa Cruz, Alonso de, Crónica de Carlos V, vol. I, p. 370.

${ }_{97}$ La primera víctima comunera que hemos documentado se produjo en Guadalajara. El duque del Infantado comunicaba el 21 de junio al cardenal Adriano que había pacificado la ciudad tras ahorcar a un
} 
Mendoza ordenó, además, ahorcar a otros dos líderes comuneros "de los más culpados" -de los que desconocemos sus nombres- y azotar públicamente a otras cinco personas más. También dirigió sus represalias contra las casas de seis líderes huidos, "que tenían oficio de síndicos y sota capitán”, las cuales ordenó derribar. En una mezcla de rigor controlado y de prudente generosidad, el 4 de septiembre Mondéjar, aún en Baza, concedió un perdón general a los vecinos de la ciudad, de sus arrabales y de los lugares de Zújar, Caniles y otros de su tierra, "así cristianos viejos como nuevos"98, de todo lo que hubiera sucedido de dos meses a esa parte, pero excluyendo expresamente del mismo a veinte de los cabecillas: a unos para que se les confiscaran todos sus bienes, "porque fueron los principales revolvedores del negocio", y a otros para que se les impusiese algún tipo de multa con que subvenir a los gastos de la tropa ${ }^{99}$. El resto de detenidos fue puesto en libertad "porque la ciudad no se despoblase y quedase destruida", confiando así en el regreso de la parte del vecindario que había huido.

Pero, lo más interesante es que poco antes de morir ejecutado Francisco Mercador otorgó testamento e hizo descargo de su conciencia ante un escribano público, documentos que se han conservado y que presentamos en primicia en este trabajo.

\section{3. "Que nadye traya luto por mi”: análisis de las últimas voluntades de Francisco Mercador}

Como colofón a esta intensa vida, analizamos de modo somero el testamento y un memorial de descargos del capitán de la Comunidad de Baza que transcribimos en apéndice y que, sorprendentemente, han pasado desapercibidos por los investigadores; seguramente porque no los relacionaron con el líder militar de los comuneros bastetanos y porque en ambos testimonios tampoco se hace alusión expresa a su inmediato y trágico destino ${ }^{100}$. Sin embargo, conocido el contexto en que se otorgaron ambos documentos, aparentemente similares a otras disposiciones de últimas voluntades, resultan impresionantes y ganan en dramatismo. Podemos imaginarnos a un Mercador, quizás herido y desde luego angustiado - como lo indicaría su temblorosa firma- dictando sus últimas voluntades a su convecino, el escribano público Diego de Ahedo, y entregándole un memorial de descargos, escrito de su puño y letra en una letra bastante cursiva - sin duda, redactado a vuela pluma durante su breve prisión-; todo ello en presencia de los dos alguaciles del

\footnotetext{
tal Pedro de Coca, carnicero o carpintero local, que era el capitán de su Comunidad. Pérez, Joseph, La revolución de las Comunidades, p. 168.

98 Este dato desmentiría, al menos parcialmente, a algunas de las últimas investigaciones, que mantenían que los moriscos locales se mantuvieron ajenos a la revuelta. CAstillo Fernández, Javier, "Conflictos y protestas populares en el reino de Granada (1504-1521)”, p. 199 y TristÁn GARcía, Francisco, "Baza, 1525: (un estudio de la sociedad a través de un padrón de cristianos viejos)", p. 398.

99 AGS, Patronato Real, leg. 3-173, fols. 830r-v.

100 Entre ellos, el propio cronista local de Baza, Luis Magaña, que fue el primero en explotar, a comienzos del siglo XX, la riquísima información de los protocolos notariales de la ciudad y que se ocupó expresamente de la revuelta comunera local en su emblemática Baza histórica.
} 
marqués de Mondéjar que lo custodiaban, Hernando Tejerina y Sebastián de Peñalosa ${ }^{101}$, y presumiblemente solo momentos antes de su ejecución.

Pero es que, además, este memorial de descargos (documento 2) tiene la excepcional particularidad de haber sido escrito al dorso de una "carta mensajera", hasta ahora también desconocida e inédita, remitida por los síndicos y capitán de la Comunidad de la ciudad de Lorca a sus iguales de la de Baza: posiblemente el único documento original de los rebeldes lorquinos que se haya conservado (documento 3).

El testamento (documento 1), bastante breve, presenta la estructura habitual de estos documentos, que ordenaban el legado espiritual y material de los que iban a morir ${ }^{102}$. Sin detenernos en las mandas religiosas - muy parcas, por otra parte- y en la declaración de hallarse sano de mente y de cuerpo -aunque, como señalamos, es posible que estuviera herido a consecuencia de los combates-, llama la atención su expreso deseo de que nadie trajera luto por él: una cláusula quizás relacionada con la recomendable moderación en las manifestaciones externas del duelo y las exequias, como los llantos multitudinarios, los rasgamientos de ropajes y otros excesos y "vanidades" rechazadas tanto por la Iglesia como por algunas ordenanzas municipales ${ }^{103}$.

Pero, sin duda, lo que más destaca en el documento son diversos aspectos propios de la condición nobiliaria del otorgante. En primer lugar, la existencia de sendos vínculos: uno, establecido años atrás por su difunta esposa a partir del tercio de sus bienes, a favor de su hija mayor, Juana de Buiza, y otro, que se fundaba en ese momento por el propio condenado, a favor de su segunda hija, Luisa, basado en un conjunto de tierras valoradas en 50.000 maravedíes y sobre las que establecía "que no las pueda vender y perpetuamente queden binculadas por mayoradgo en su hijo mayor"; y, a falta de tal, pasaría al heredero de su hermana.

Otro rasgo de distinción es la existencia de una capilla familiar en la Iglesia Mayor de Baza - donde estaba sepultada su esposa ${ }^{104}-$, sobre la que Mercador ordenaba instituir una capellanía, regida por su hermano el canónigo Baeza (y en cuyo patronazgo sucederían sus herederos), a la que se le asignan las rentas de un conjunto de seis censos para financiar tres misas semanales por su eterno descanso. También establecía una pequeña obra pía, consistente en vestir a un pobre anualmente en la festividad de la Encarnación.

\footnotetext{
101 Peñalosa, de la clientela de los capitanes generales, desempeñaría el cargo de veedor de la gente de guerra del Reino de Granada en el sector de Levante entre 1539 y 1547. Jiménez Estrella, Antonio, Poder, ejército y gobierno en el siglo XVI, p. 460.

102 Martín Cea, Juan Carlos, "El modelo testamentario bajomedieval castellano y su reflejo en los diferentes grupos sociales”, pp. 103-156.

103 Paulino Montero, Elena, "Encuentro con lo sagrado y conmemoración familiar. Las ceremonias funerarias de los Velasco en Santa Clara de Medina de Pomar (1383-1471)”, p. 167.

104 La capilla se había erigido en tiempos y con licencia del primer abad de Baza, Pedro Montano (15041513/1514), y estaba situada a mano izquierda de la capilla mayor, pero en 1538, durante las obras de reconstrucción y de ampliación de la cabecera del templo -tras el terremoto de 1531- fue derribada y los cuerpos trasladados a otra ubicación, a pesar de las protestas de los herederos de Mercador. AMdlH, "Escritura en que llaman en Baza el comendador a mi revisabuelo. Año de 1538".
} 
En fin, otros signos de riqueza que aparecen, propios de ese estatus social preheminente alcanzado a lo largo de su vida, es una pequeña fortuna valorada -a partir de las alusiones al tercio y quinto de sus bienes- en, al menos, 150.000 maravedíes, o la presencia de criados, como Catalina de Madrid ${ }^{105}$, con la que había tenido un hijo bastardo, Francisco, aún menor de edad, cuya crianza encomendaba a sus dos hijas y al que legaba, cuando cumpliera veinte años, 30.000 maravedíes procedentes del quinto de libre disposición. Por último, nombraba como albaceas a su hermano el canónigo y a Lope de Saravia, su antiguo lugarteniente en las tareas de reclutamiento para Orán ${ }^{106}$, y nombraba como sus universales herederas, por iguales partes, a sus dos hijas legítimas. Por último, llama la atención que el testamento solo va firmado, con una rúbrica bastante temblorosa, por el otorgante, sin que figuren las suscripciones de los testigos ni del notario.

Por su parte, en el memorial de descargos de su "ánima e conçiençia", además de reconocer diversas deudas pecuniarias, destaca el arrepentimiento por distintas acciones violentas e ilegales cometidas a lo largo de su vida, como un delito inespecificado contra el abuelo de unos moriscos de Galera, cierta madera "y otras cosas" sustraídas en Purchena, "otras menudencias" en Huéscar o una compensación a los pobres del Río de Almería, porque "quando yva a Orán" les mató muchas gallinas. Todo lo cual nos remite, de nuevo, a una personalidad arrogante y quizás agresiva, por otra parte bastante común entre las clases privilegiadas de la época. Finalmente, también alude a tres piezas de artillería traídas desde la fortaleza de Mojácar, sin duda durante la reciente revuelta, que ordenaba reintegrar.

\section{La memoria desfigurada: entre el comendador Francisco Vázquez de Acuña y el proscrito "Mercadillo"}

Como suele ocurrir con los perdedores de un conflicto, el recuerdo de los comuneros de Castilla, tildados de traidores a la Corona, quedó relegado cuando no vilipendiado durante décadas; en realidad durante las siguientes centurias, hasta que los liberales del siglo XIX reivindicaran y reelaboraran su legado en clave antiabsolutista y democrática ${ }^{107}$. El caso de las "alteraciones" de Baza no fue distinto. Durante el siglo XVI, cuando se aludía de pasada a este asunto traumático se procuraba eludir su transfondo político y los aspectos más escabrosos ${ }^{108}$, especialmente por parte de los descendientes de los perseguidos, mientras que el relato oficial reduciría a los líderes del movimiento

\footnotetext{
105 Podría tratarse de la misma Catalina de Madrid, viuda de Hernando de Bazán, y madre de varios hijos, que en 1515 se vio obligada a vender dos fincas a varios moriscos de Caniles por 8.000 maravedíes. AHCNA-G, Baza, Prot. 4, fols. 22v-24r.

106 Este ganadero de origen judeoconverso ocuparía una juradería en el concejo de Baza entre 1525 y 1533.

107 Véase Maravall, José Antonio, Las Comunidades de Castilla: una primera revolución moderna.

108 Así, cuando en 1562 el hijo de una antigua esclava del jurado Mercador promueva una probanza para demostrar su condición de liberto, uno de los testigos presentados afirmaría que "fue público en la dicha çiudad, que por tal lo sé, que al tienpo que degollaron al dicho Mercador dexó horra e libre a la dicha María de Mercador o que la ahorró Luisa de Buiza, su hija”. AHCNA-G, Baza, Prot. 51, fol. 456.
} 
prácticamente a la categoría de delicuentes comunes. En nadie se puede ejemplificar mejor esta doble, interesada y manipulada visión del pasado que en la figura de Francisco Mercador, quien al igual que en vida tuvo dos identidades, tras su violenta muerte generó, de forma paralela, dos personajes contrapuestos e igualmente alejados de su figura histórica real.

\subsection{La historia familiar "blanqueada": o la invención de una ascendencia aristocrática}

Como hemos indicado Francisco Mercador dejó dos hijas legítimas que adoptaron el apellido materno, seguramente por su mejor prosapia. Al menos una de ellas, Juana de Buiza, tuvo una amplia descendencia tras casar con Luis de Ribera, un escribano originario de Quesada que ocupó la escribanía del concejo de Baza al poco de la ejecución de su suegro. Por supuesto ninguno de sus nietos llevó el apellido del abuelo ajusticiado y baldonado. Pero tampoco parece que tuvieran problemas de proscripción social a lo largo de las décadas posteriores a la revuelta, pues formaron parte de la oligarquía local, alcanzaron empleos públicos de la Corona y enlazaron con familias del mismo nivel social. Así, Luis de Ribera heredó la escribanía de concejo de su padre homónimo, el licenciado Alonso Lara de Buiza fue regidor de Baza (1567-1574), corregidor de Guipúzcoa (1568-1571), alcalde de la Cuadra (sala del Crimen) de la Audiencia de Sevilla y, desde 1580, alcalde mayor y oidor de la Audiencia de Galicia ${ }^{109}$, y Álvaro de Buiza sucedió en la regiduría del cabildo bastetano a su hermano (1574-1575), mientras que Ana de Lara casó con Francisco de Peralta, también regidor de la ciudad e hijo del edil del mismo nombre. Sin embargo, sus descendientes -como muchas otras estirpes que contaban con algún ascendiente "notado" racial, religiosa o políticamente- optaron por manipular su verdadero origen, a través de falsificaciones documentales y genealógicas, aprovechando la ocasión además para encumbrarlo/encumbrarse socialmente. Y para ello los Lara de Buiza no tuvieron empacho en convertirse en descendientes de un bastardo. Para el caso que nos ocupa, tuvimos ocasión de consultar hace tiempo parte del fondo documental de esta familia, que constituye uno de los diversos linajes que se acumularon y se conservan en el archivo privado de los marqueses de la Hermida ${ }^{110}$. Los documentos de la estirpe de los Mercador-Buiza resultan muy interesantes porque nos

\footnotetext{
109 También obtuvo, hacia 1579, el hábito de la pretenciosa y recién creada Orden de San Esteban de Toscana. En la información extractada de su expediente -que se conserva en el Archivo de Estado de Pisa- figuran estos datos: "Licenciado Alonso de Lara de Buiza, alcalde de Sevilla, natural de la ciudad de Baza (Granada), hijo de Luis de Lara Ribera y Acuña, y de doña Juana de Buiza y Mercaderes (sic); nieto materno de Francisco de Mercaderes (sic), decapitado en Sevilla (sic) como noble. Se le concedió el hábito, pero no consta si llegó a vestirlo (B.C. I, 39)". Ceballos-Escalera Gila, Alfonso de y Cercós García, Luis F.: "Los españoles en la Orden de San Esteban de Toscana (caballeros, pretendientes, falsarios)", p. 12.

110 Este título, creado a finales del siglo XVIII, fue rehabilitado en 1896 por don Nicolás Santa Olalla Rojas, que descendía -entre otras- de diversas familias de origen bastetano. Pudimos consultar parte del archivo familiar hace más de veinte años en el domicilio granadino de su anterior titular, don Francisco de Santa Olalla Montañés († 2016).
} 
permiten conocer la génesis y desarrollo de la manipulación de la memoria del capitán de la Comunidad de Baza desde prácticamente la fecha de su muerte. Y encontramos desde actuaciones bastante burdas a otras más elaboradas que lograrían conseguir, prácticamente en dos generaciones, borrar toda mácula e incluso desdibujar la identidad real del abuelo comunero y convertirlo en un personaje de mejor alcurnia. Veámoslo.

La primera estrategia que usaron sus descendientes fue la de elevar su estatus nobiliario -que indudablemente ya posesía- convirtiéndolo en comendador de la Orden de San Juan de Jerusalén. Así, en las portadas de las carpetillas que conservan y describen diversos traslados notariales de escrituras familiares se encuentran anotaciones del siguiente tenor: "escritura en que llaman al dicho señor comendador, en Purchena, comendador. Año de 1517" "111, "escritura en que llaman en Baza el comendador a mi revisabuelo [tatarabuelo]. Año de 1538" o "escritura en que llaman al comendador en Cazorla comendador", esta del año 1520. Por supuesto, en el más de centenar de documentos originales que hemos compilado sobre Francisco Mercador / Francisco de Baeza nunca aparece con tal título, lo que indica que estos traslados fueron convenientemente manipulados para convertir al escudero en comendador de tan insigne Orden militar ${ }^{112}$; hipótesis avalada por la misma insistencia y reiteración de esta supuesta condición en las regestas que encabezan las portadillas de los documentos del archivo familiar. En alguna de las genealogías elaboradas por la familia, o por algún especialista contratado al efecto, se alude de puntillas a su ejecución, destacando eso sí, que fue degollado -signo indudable de nobleza- Así, por ejemplo, en un documento donde se recopilan algunos linajes nobles de Quesada y Cazorla se alude a nuestro personaje en estos términos: "y muerta su mujer tomó el ábito de San Juan y por çierta desgracia (sic) murió degollado" ${ }_{113}$.

La segunda estrategia, y a la postre la más existosa, fue modificar la ascendencia y el apellido de su infortunado antepasado para convertirlo, de un plumazo, no en hijo de unos modestos hidalgos de Cazorla - de más que posible ascendencia judeoconversasino en, nada menos, que hijo bastardo de don Lope Vázquez de Acuña, II conde de Buendía y adelantado de Cazorla entre 1477 y 1486. Por supuesto, una vez más, en los documentos de la época no existe alusión alguna a este presunto hijo espurio, ni aparece tal en las últimas voluntades del conde ${ }^{114}$.

\footnotetext{
111 Este documento cuenta, además, con una burda enmienda, pues se aprecia que sobre el texto original se ha raspado el patronímico originario y añadido sobre él el de Acuña.

112 Tampoco hemos localizado referencia alguna en la serie de expedientes de caballeros de esta Orden que se conservan en el Archivo Histórico Nacional. Véase Javierre Mur, Áurea Lucinda, Pruebas de ingreso en la Orden de San Juan de Jerusalén y Portal de Archivos Españoles: Archivo Histórico Nacional, Expedientes de pruebas de caballeros de la orden de San Juan de Jerusalén. Gran Priorato de Castilla y León (1514-1798): http://pares.mcu.es/ParesBusquedas20/catalogo/description/2161989 [25 enero 2020].

113 AMdLH, no 36, "Escritura de la Cofradía del Santísimo Sacramento de la villa de Quesada donde hai muchas noticias que inportan".

114 Testamento otorgado en Dueñas el 25 de octubre de 1489 (RAH, SyC, 9-288, fols. 114 a 117). En el designa como herederos a sus tres hijos varones -Juan, Pedro y Fadrique- y a sus nueve hijas, nombra como albaceas a sus hermanos don Pedro y don Luis de Acuña (este obtuvo numerosas mercedes en el repartimiento de Baza) y comisiona a su cuñado don Enrique Enríquez de Guzmán, mayordomo del rey y futuro potentado en Baza, para que consiga ventajosos matrimonios para sus hijas.
} 
De este modo, el jurado de Baza comenzará a aparecer en los documentos familiares con un apellido doble: Francisco Mercador de Acuña. Y el instrumento que avaló esta ascendencia fue una ingeniosa falsificación. Para ello se partió de un documento auténtico, la real provisión de 1511 que concedía el blasón a Francisco Mercador por sus destacados hechos de armas en el cerco de $\mathrm{Baza}^{115}$, en el que se interpolaron frases que lo convertían en hijo natural del adelantado de Cazorla, como se señala en la transcripción y confrontación de ambos que se ofrece en el apéndice documental 4 . Y todo esto quedó avalado cuando el "ilustre señor" Alonso de Lara y Buiza, regidor de Baza y letrado con diversos destinos públicos, presentó el documento falsificado -"un previllegio de harmas que la reyna doña Juana, de gloriosa memoria, conçedió al comendador Francisco Mercador de Acuña, mi agüelo"- y solicitó y obtuvo un traslado del mismo, ya totalmente legalizado, expedido ante el licenciado Salazar, miembro del Consejo de $\mathrm{Su}$ Majestad y alcalde de su Casa y Corte ${ }^{116}$.

Esta suerte de patronímico puente, "Mercador de Acuña”, pasaría a convertirse, a comienzos del siglo XVII en un flamante Francisco Vázquez de Acuña, por obra y gracia de un genealogista del prestigio de Alonso López de Haro; el cual, cuando recogió en su obra a este nuevo personaje y a su descendencia, no tuvo empacho alguno en asegurar: "todo lo qual me consta por escrituras auténticas, hazientes fe, que originalmente han llegado a mis manos" ${ }^{117}$. Y, a partir de ese momento, quedó perpetuada esta falsificación, que otorgó carta de naturaleza al inexistente linaje de los Vázquez de Acuña de Baza, que se recoge y se ha reproducido, hasta la saciedad, en buena parte de las historias genealógicas y locales hasta nuestros días ${ }^{118}$.

\subsection{La leyenda negra: el “aventurero” Mercadillo}

Como ya se ha indicado, los comuneros y sus líderes, como traidores a la Corona, fueron criminalizados y proscritos hasta el final del Antiguo Régimen e, incluso, con posterioridad. Este también fue el caso de Francisco Mercador, pero con una diferencia notable, pues su recuerdo real fue sepultado rápidamente al mismo tiempo que emergía

\footnotetext{
115 La copia del original expedido por la Cancillería real se conserva en AGS, RGS, 1511-I, fol. 113.

116 El traslado fue librado en Madrid, el 15 de enero de 1572, por el escribano Gregorio Fernández del Busto. AMdLH, no 39, "Armas de los Buizas".

117 "Decendencia de los Acuña de la ciudad de Baça". A pesar de los documentos supuestamente auténticos alegados, el propio genealogista advirtió algún error -más bien otra falsificación-, que le obligó a convertir al bastardo en caballero de la Orden de Santiago: "Ay mucha memoria de este caballero en el libro del Repartimiento de la ciudad de Baça, hecho por los Reyes Católicos, y en la lista y padrón de los demás cavalleros ganadores desta ciudad, dize fue cavallero del hábito de Calatrava, parace que fue error del que lo escrivió en el libro, porque los cavalleros desta Orden no se casavan, hasta el año de quinientos y quarenta, por bula de Paulo Tercero". LóPez De Haro, Alonso, Segunda parte del nobiliario genealógico de los reyes y títulos de España, pp. 15-16.

118 Véase, por ejemplo, Arco y Molinero, Ángel del, Glorias de la nobleza española, pp. 139-140; FerNÁNDEZ DE BÉTHENCOURT, Francisco, Historia genealógica y heráldica de la monarquía española, vol. 3, p. 167; Magaña VisBal, Luis, Baza histórica, pp. 251 y 296.
} 
y se perpetuaba en la memoria colectiva y a través de la cronística y las historias locales una suerte de anti-héroe motejado con el despectivo diminutivo de "Mercadillo", envés del glorioso don Luis Hurtado de Mendoza, capitán general del Reino de Granada y dominador de la Comunidad de Baza.

La referencia más antigua a Mercadillo que hemos localizado hasta el momento data de comienzos del siglo XVII, si bien permaneció inédita hasta finales del siglo XIX. En efecto, en la segunda parte de la biografía de Felipe II debida al cronista real Luis Cabrera de Córdoba, al resaltarse la decidida intervención de don Luis Hurtado de Mendoza contra los rebeldes de Baza y Huéscar, se afirma:

"Fue el primero que salió contra los Comuneros en el año de mil quinientos y veinte, y los rompió en la villa de Baza, y cortó la cabeza á Mercadillo su capitán, y le quitó la ciudad de Huelva (sic, por Huéscar) y las banderas y estandarte"119.

Pero la primera cita publicada la localizamos en una conocida obra del cronista regio Gil González Dávila, aparecida en 1623, en la que una vez más al glosar la vida y hazañas del segundo marqués de Mondéjar, afirmaba en términos muy parecidos -sin que se pueda establecer quién copió a quién, o si ambos bebieron de una fuente común- que fue el capitán general:

“el primero que se opuso con exército a los Comuneros el año 1520, desbaratólos en Baça, ganó sus estandartes, corto la cabeça a su Capitán Mercadillo, ganó la ciudad de Guéscar, que la tenía usurpado, y por aquellas partes puso en sosiego a la gente Comunera" ${ }^{120}$.

Y en esta suerte de letanía de los méritos del primer héroe anticomunero de Castilla volvemos a encontrar la inevitable referencia a Mercadillo en la inédita historia genealógica de los Mendoza granadinos, redactada a finales del siglo XVII por el heredero consorte del título: el erudito Gaspar Ibáñez de Segovia, que copia a la letra a González Dávila ${ }^{121}$. Ya entrado el siglo XIX, la historia del reino de Granada de Lafuente Alcántara siguió al manuscrito de Ibáñez de Segovia al tratar del suceso comunero, pero introdujo de su propia cosecha el matiz "aventurero" y revolucionario de Mercadillo, personaje al que hace parecer ajeno a la región y que habría llegado para inflamar la revuelta en buena parte del Sureste, y del que -sin embargo- ya no recoge su infausto final:

\footnotetext{
119 Cabrera de Córdoba, Luis, Filipe Segundo, Rey de España, 1877, vol. 3, p. 354. La primera parte de esta obra se publicó en 1619.

120 GonzÁlez Dávila, Gil, Teatro de las grandezas de la villa de Madrid, p. 361.

121 Historia de la Casa de Mondéjar, Biblioteca Nacional de España, Mss/3315, Libro 4, cap. 6. "Sosiega y extingue el Marqués las comunidades en el Reyno de Granada en ausencia del Emperador”, fol. 289.
} 
"La revolución de los comuneros en tiempo de Carlos V se dejó sentir en el reino de Granada (...) Comenzó el alboroto en la parte oriental del reino de Granada en los confines de Murcia y adelantamiento de Cazorla: puso en combustión al país un aventurero llamado Mercadillo; hizo huir al adelantado D. García de Villarroel y se apoderó de Huéscar, logrando que Baza y su término apoyase su alzamiento" "122.

Imagen que reprodujeron, a partir de entonces, otros autores, como Muñoz y Gaviria, que lo motejará de "audaz aventurero"123, o ya en pleno siglo XX el cronista bastetano Magaña Visbal, que utilizará los mismos adjetivos:

“Un aventurero, el famoso Mercadillo, proclamó en esta parte los mismos principios que los comuneros en Castilla y se erigió en adalid de la causa que conmovió a España entera en 1520. Audaz hasta el extremo, entra en las villas y ciudades, siembra en ellas sus doctrinas de rebelión y arrastra en pos de sí a una enorme muchedumbre que le ayuda a apoderarse de Huéscar, no tardando en conseguir que la ciudad de Baza y gran parte de los pueblos del distrito secunden su atrevido movimiento (...) El propio marqués (...) logró hacer huir a la mayor parte de los insurgentes, que se refugiaron en Huéscar con el audaz Mercadillo, y castigó con mano dura a cuantos revoltosos pudo aprisionar" ${ }^{124}$.

También evocó las andanzas del "tristemente célebre Mercadillo" Cáceres Pla" ${ }^{125}$, a quien siguió el inefable cronista almeriense Tapia Garrido, que en su monumental historia almeriense de finales del siglo XX -sin duda por una errónea interpretación del trabajo antecedente del erudito lorquino-, en el colmo de la deformación histórica, lo convirtió nada menos que en un insurgente líder morisco ${ }^{126}$.

De este modo se manipuló la historia, y se sepultó la memoria, del desdichado jurado Francisco Mercador, capitán de la Comunidad de Baza.

122 Lafuente Alcántara, Miguel, Historia de Granada, tomo IV, pp. 179-180.

123 MuÑoz y Gaviria, José, Historia del alzamiento de los moriscos, p. 102.

${ }^{124}$ Nuestro cronista recoge -sin advertir que en origen se trataba de la misma persona- las trayectorias del supuesto conquistador Francisco Vázquez de Acuña y del comunero Mercadillo en su clásica obra. Magaña Visbal, Luis, Baza histórica, pp. 296 y 378-381, respectivamente.

${ }^{125}$ Este autor amplió el área de influencia de la revuelta de Mercadillo hasta el marquesado del Cenete: comarca donde no consta rebelión comunera alguna. CÁceres Pla, Francisco, "Moros y moriscos en España en el siglo XVI", pp. 16-17.

126 Según él, en el Cenete y la Hoya de Baza, "un morisco llamado Mercadillo incitó a sus correligionarios a alzarse y arrojar a los cristianos del reino de Granada; pero los moriscos no le hicieron caso, antes se unieron a los cristianos y los apresaron". Véase su capítulo "Comuneros en el entorno" en TAPIA GARRIDO, Ángel, Historia General de Almería y su provincia, vol. 7, p. 306. 


\section{Apéndice Documental}

\section{Documento 1.}

1520, agosto, 31. Baza

Testamento del jurado Francisco Mercador, capitán de la Comunidad de Baza.

AHCNA-G, Baza, Prot. 12, Diego de Ahedo, fols. 1013r-1014v.

[Al margen: "Testamento de Francisco Mercador, jurado"]

"In dey nomine, amén. Sepan quantos esta carta de testamento vieren como yo, Francisco Mercador, jurado, vecino que soy de la noble çibdad de Baça, estando sano del cuerpo y en mi seso y entendimiento natural, tal que Nuestro Señor tovo por vien e le plugo de me lo dar, creyendo como creo en todo lo que tiene e cree la madre Santa Yglesia de Roma e viendo cómo las cosas deste mundo son falleçederas e las del otro durables para sienpre jamás, otorgo e conosco que hago en fecho de mi ánima e ordeno este mi testamento e postrimera voluntad en la forma syguiente:

- Primeramente, encomiendo mi ánima a Dios que la crio e la redimió por su presçiosa sangre e le pido aya della misericordia [y] la lieve a su santo reyno de parayso con sus santos, amén. E mando el mi cuerpo a la tierra, donde fue formado.

-Yten, mando que quando a nuestro señor pluguiere de levar mi ánima de esta vida, que mi cuerpo sea sepultado en la yglesia de Santa María desta çibdad, en mi capilla, en la misma sepultura de Teresa de Boyça, mi legítima muger. E mando que el día de mi enterramiento o luego otro día syguientes me digan una misa cantada con su vegilia de nueve liçiones. E luego los nueve días syguientes me digan nueve misas, según que le paresçiere al canónigo Baeça, mi hermano. E todo sea ofrendado de pan e vino y çera y se pague de mis bienes lo que es costunbre.

-Yten, mando que en el conplimiento de mi ánima, de misas e obras pías se haga como a mi hermano el canónigo le paresçiere e lo mandare, porque con él tengo platicado e hablado. E lo remito a él, con tanto que nadye traya luto por mi. / [fol. 1013v]

-Yten, mando que tres mill maravedís de çenso perpetuo que tengo contra los bienes y herederos de Lope Sánchez, cortidor, y mill maravedís de çenso perpetuo que tengo contra los bienes [tachado: y herederos] de Pedro Hernández, tinturero, y quinientos maravedís de çenso perpetuo que tengo contra el Xergalí, christiano nuevo, y ocho reales de çenso perpetuo que tengo contra Luis de Hontiveros, y ocho reales de çenso perpetuo que tengo contra Pedro de Cospineda, y seis reales de çenso perpetuo que tengo contra el Bacarexí, mando que todo esto sea para una capellanía, perpetuamente para syenpre jamás, para la dicha mi capilla de Santa María desta çibdad, en la qual se digan cada semana perpetuamente tres misas: la una por las ánimas de Purgatorio y la otra del Espíritu Santo y la otra a Nuestra Señora, porque Dios aya misericordia de mi 
ánima. E que desta capellanía sea patrón el dicho canónigo Baeça, mi hermano, en su vida, y después mis yernos y nietos y suçeda en mis herederos. Y destos çinco mill e tantos maravedís se dé de pitança al capellán que [roto] dicho canónigo sufiçiente, y el resto para reparos y ornamentos de la dicha capilla, por manera que todo se gaste cada año en ello.

-Yten, mando una huerta que tengo en el Lomo, que la conpré del Herruz, que se açensúe o arriende, e con la renta cada año perpetuamente bistan un pobre el día de nuestra señora de la Encarnaçión. E que desto tenga cargo el dicho capellán e se cunpla e lo hagan estar al dicho pobre en la dicha capylla.

-Y porque mi muger, que santa gloria aya, mejoró a Juana de Boyça en el terçio de su hazienda con condiçión que en fin de mis días yo mejorase a Luisa, mi hija, en el terçio de mis bienes, que la mejoro a la dicha Luisa en çinquenta mill maravedís. Los quales le señalo en las tierras que conpré de Bayón y en las tierras que conpré de Hernando de la Queva, con otras que están cave ellas. A la qual pongo gravamen para que no las pueda vender y perpetuamente queden binculadas por mayoradgo en su hijo mayor. Y asy, sy no los oviere ella que los aya el hijo o heredero de Juana de Boyça con el mismo gravamen que no las pueda vender. $Y$ asy suçeda de heredero en heredero para sienpre.

-Yten, mando a Francisco, mi hijo bastardo y hijo de Catalina de Madrid, mi criada, que lo críen mis herederos. E quando sea de hedad de veynte años que le den treynta mill maravedís, los quales le mando por vya del quinto de mis bienes. Y aunque el quinto balga más, mando que con esto se contente.

-Yten, mando que [tachado: dos mem-] un memorial que dexo en poder del escribano deste testamento, firmado de mi nonbre en las espaldas de una carta mensajera, se cunpla como en él se contiene porque es descargo de mi ánima e conçiençia.

E para conplir e pagar este mi testamento e todo lo en él contenido dexo por mis alvaçeas e testamentarios al canónigo Sabastián de Baeça, mi hermano, y a Lope de Saravia [tachado: mi hermano] vecinos desta çibdad, a los quales juntamente e a cada uno yn solidun doy todo mi poder conplido para que puedan entrar e tomar tanto de lo mejor parado de todos mis bienes hasta que cunplan e paguen este dicho mi testamento e todo lo en él contenido, e lo que el dicho canónigo mi hermano ordenare en lo de las misas e pías causas de mi ánima.

E despues de conplido e pagado este mi testamento e todo lo en él contenido dexo por mis hijas legítimas y universales herederas en todos mis bienes a las dichas Juana de Boyça e Luisa, mis hijas e hijas de la dicha Teresa de Boyça, mi legítima muger. Las quales mando que los ayan y hereden todos generalmente e los partan por partes yguales, tanto la una como la otra e la otra como la otra.

E por esta carta reboco e anulo e doy por ningunos e de ningún valor y efeto otros qualesquier testamentos que hasta agora aya fecho e ordenado, los quales ni alguno dellos no quiero que balgan en juizo ni fuera de él en caso que parescan, salvo este mi testamento que agora fago e ordeno, el qual mando que balga por mi testamento e por 
mi cobdeçillo e por mi postrimera voluntad e en la mejor forma e manera que puede e deve valer de derecho. En fe de lo qual, otorgué esta carta de testamento ante Diego de Ahedo, escribano público, e testigos yusoescritos, en el registro del qual firmé mi nonbre.

Que fue fecha e otorgada en la dicha çibdad de Baça, en treynta y un días del mes de agosto año del nasçimiento de nuestro salvador Ihesu Christo de mill e quinientos e veynte años. Que fueron presentes al otorgamiento della Christoval de Bezilla, clérigo benefiçiado en la çibdad de Purchena, e Hernando Texerina e Savastián de Peñalosa, alguaziles del ylustre señor el marqués de Mondéjar, conde de Tendilla, capitán general del reyno de Granada y escuderos de su capitanía, vecinos de la çibdad de Granada.

\author{
Francisco Mercador" \\ [firmado y rubricado con dificultad]
}

\title{
Documento 2.
}

Sin fecha [c. 1520, agosto, 31. Baza].

Memorial de descargos ológrafo de Francisco Mercador.

AHCNA-G, Baza, Prot. 12, Diego de Ahedo, fol. 1015r-v.

"Los cargos de conçiençia.

En Caçorla está un hijo de Diego de Bedmar. Su padre me vendió unas casas y eran de aquel moço. Pienso que le soy en cargo de diez mil maravedís ${ }^{127}$.

A un Guerrero, que le vendí las casas donde vive Jentyl, le soy en cargo de myl maravedís.

A unos cristianos nuevos de [tachado: Orçe] Galera, por çierto delito que yo hize a un avuelo suyo, mando que le den tres mill maravedís.

\footnotetext{
$\overline{127}$ Esta vivienda, a su vez, había sido traspasada en 1512 por Mercador a un tal Diego Ruiz Matero por 8.000 maravedíes (AHCNA-G, Baza, Prot. 2, fols. 316r-317v). Al poco de la ejecución de Mercador, su hermano y albacea, el canónigo Sebastián de Baeza, acudió a Cazorla a saldar esta presunta deuda con Francisco Bedmar, hijo de Diego Bedmar, a lo que este declaró: "Agora paresçe que el tienpo que el dicho señor comendador Francisco Mercador, que nuestro señor perdone, fallesçió de esta presente vida, estando en su última voluntad como persona temerosa de Dios, no enbargante que no me hera obligado a cosa alguna çerca de lo susodicho, declaró que pensava que hera en cargo de diez mil maravedíes de las dichas casas". En cualquier caso, el canónigo le compensó con un joven esclavo negro atezado. AMdLH, traslado de la escritura otorgada en Cazorla, el 16 de octubre de 1520.
} 
A Martín ¿Áñez? devo mil maravedís ${ }^{128}$.

A Avezilla le devo seis ducados ${ }^{129}$.

Un ducado me hallé en la plaça. Denlo por Dios.

En Purchena mando que se den çinco ducados a proves [sic] porque bos e tomado mucha madera y otras cosas. Al alcaide de Çújar mando que le den un castellano ${ }^{130}$. A Juan Hurtado mando que le den dies reales ${ }^{131}$. De Muxácar truxe un ¿terciado? y un [sic] espingarda y un ¿tronezu[e]lo?, vuélvanlo. De Huésca[r] mando que den doze hanegas de trigo y una mesa y un castellano a proves por otras menudençias que allí tenía. Quando yva a Orán destruí en el río de Almería muchos gallinos, den a los proves del río de Almería tres ducados.

A los [h]erederos de Miguel García devo mil maravedis. Devo al bachiller Vaena ocho ducados" ${ }^{132}$.

(fol. 1015v) "Esto desta otra parte son los cargos que tengo y los devo ciertamente. Se an de pagar de mis vienes. Francisco Mercador" [firmado y rubricado]

\section{Documento 3.}

1520, agosto, 25. Lorca

Carta de la Comunidad de Lorca a la de Baza.

AHCNA-G, Baza, Prot. 12, Diego de Ahedo, fol. 1015r-v.

(fol. 1015r) "A los nobles señores, los syndicos e capitán de la çibdad de Baça"

(fol. 1015v) "Nobles señores,

\footnotetext{
${ }^{128}$ Quizá se trate del influyente mercader y arrendador de impuestos, de más que probable origen converso, Martín Yáñez de Ávila, muy pujante en la Baza de la época y que también sería mayordomo de propios del concejo bastetano. CAstillo Fernández, Javier, "Negocios de familia": el perfil institucional y social de los mayordomos de propios del Reino de Granada (1492-1550)", pp. 43-44. A comienzos de 1520 Mercador había suscrito una obligación a favor de este recaudador por la compra de un cantidad de trigo y cebada. AHCNA-G, Baza, Prot. 8, fol. 6.

${ }^{129}$ Podría tratarse el clérigo Cristóbal de Vecilla, beneficiado de Purchena, que figura como testigo en su testamento y que con el tiempo llegó a ser vicario de esa ciudad almeriense.

${ }^{130}$ Lo era entonces Pedro de la Serna, miembro de la oligarquía de Baza y criado de los Enríquez.

131 Se trata, muy probablemente, de su colega en el concejo de Purchena, el regidor Juan Hurtado de Mendoza. Más información sobre este influyente personaje, protegido y agente del marqués de los Vélez en la comarca del valle del Almanzora, en CASTillo Fernández, Javier, Macael y Laroya en la Alta Edad Moderna (1489-1650): conquista, época morisca y repoblación, pp. 71-72.

${ }_{132}$ Debe tratarse del bachiller Diego de Baena, médico o "físico", que ejercía en Baza en esa época. ¿Quizás se trataba de la minuta por los posibles gastos de la curación de sus heridas?
} 
Vuestras merçedes escrivieron una carta a esta Comunidad y vemos por ella lo que piden. Y la verdad es que porque esa çibdad [es] tan honrada, e la Comunidad della, nos otros holgamos de toda hermandad, pues que syendo aquí tan juntas estas dos çibdades ${ }^{133}$ nos convenía, mayormente que syenpre entre nos otros ha avido muy buenas obras, y sería justo que en tienpo de neçesydad, como a estas Comunidades se les ofreçe, para desagraviarse asy lo hiziésemos. Solamente vn ynconveniente nos a pareçido muy rezio: ser esa çibdad en el reyno de Granada, que pareçe que es mucha ocasyón a mover e alterar los nuevamente convertidos. Y porque las cosas de Castilla de oy más podrían yr de manera que no fuese en nuestra mano remediar lo dese reyno y esto sería en mucho deserviçio de Dios e del rey, nuestro señor. Por tanto, os pedimos por merçed soseguéys esa çibdad, e sy para esto fuere menester nuestra ayuda con todo este reyno e comarcas hazerlo hemos de buena voluntad, porque con esto cunpliremos con lo que devemos a Dios e al rey y con el de vuestras merçedes, aunque al presente les paresca otra cosa. Nuestro señor las ¿nobles? personas de vuestras merçedes guarde, para tanto bien como desean. De [Lo]rca a XXXV de agosto de XX años.

Por mandado de los señores syndicos e capitán, Pedro Felizes, escribano ${ }^{134}$ " [firmado y rubricado]

\section{Documento 4.}

1511, enero, 4. Madrid.

Real provisión de la reina doña Juana concediendo privilegio y escudo de armas a Francisco Mercador, vecino de Cazorla, con interpolaciones posteriores.

AGS, RGS, 1511-I, fol. 113. Copia del Registro del sello de Corte, y AMdLH (Granada). Traslado expedido en Madrid el 15 de enero de 1572, con interpolaciones ${ }^{135}$. Cuadernillo con leyenda en la cubierta: "No 39. Armas de los Buizas".

[En la parte superior: "Para que pueda traer armas en sus reposteros dos castillos Francisco Mercador, veçino de Caçorla. Henero I[M]DXI años”]

\footnotetext{
${ }^{133}$ La cercanía geográfica es más que discutible, pues distan más de $110 \mathrm{~km}$, pero es cierto que ambas eran las principales ciudades de realengo a ambos lados de la antigua frontera oriental del Reino de Granada y contaban con una fuerte relación a todos los niveles.

134 "Principal instigador de la Comunidad" lorquina, lo denomina Juan Francisco Jiménez Alcázar, Un concejo de Castilla en la frontera de Granada: Lorca 1460-1521, p. 473.

135 El traslado, que incluye los falsos añadidos que se indican en cursiva, se realizó ante el licenciado Salazar, del Consejo de S.M. y alcalde de su Casa y Corte, por el escribano Gregorio Fernández del Busto, a petición del ilustre señor Alonso de Lara y Buiza, regidor de Baza, quien dijo "que yo tengo un previllegio de harmas que la reyna doña Juana, de gloriosa memoria, conçedió al comendador Francisco Mercador de Acuña, mi agüelo", del que solicitó el traslado que, a partir de entonces, conservó el linaje en su archivo familiar.
} 
"Doña Juana, por la gracia de Dios, reyna de Castylla, de León, de Granada, de Toledo, de Galyzia, de Sevilla, de Córdova, de Murçia, de Jaén, de los Algarves, de Algezira, de Gibraltar, e de las yslas de Canaria e de las Yndias, yslas e tierra firme del mar Oçeano, prinçesa de Aragón e de las Dos Seçilias, de Iherusalem, archiduquesa de Abstria, duquesa de Borgoña e de Bravante, etc., condesa de Flandes e de Tyrol, etc., señora de Vizcaya e de Molina, etc. Por quanto vos, Francisco Mercador de Acuña, vesino de la villa de Caçorla, desde que fuistes de hedad de quinze años servistes al rey Fernando, mi señor i padre, e a la reyna doña Ysabel, mi señora madre, que aya santa gloria, en la guerra que touieron con el rey y moros del reyno de Granada, donde derramastes en su serviçio asaz de vuestra sangre, e fesystes otros serviçios señalados. Espeçialmente en el çerco que los dichos rey e reyna, mis señores, tovieron sobre la çibdad de Baça, vençistes dos desafíos que tovistes con çiertos moros, e salistes a ellos: la una vez del castillo del Artyllería, donde posávades, e la otra vez del castillo de la Noguera, segund paresçió por çiertos testymonios que por vuestra parte fueron presentados ante algunos de los del mi Consejo.

$\mathrm{Y}$ me suplycastes e pedistes por merçed que en remuneraçión de los dichos serviçios y de los de don Lope Bázquez de Acuña, conde de Buendía, adelantado que fue de la villa de Caçorla, vuestro padre, cuyo hijo paresçió hérades por las ynformaçiones y recaudos que ansimesmo presentastes ante los del mi Consejo, vos diese lyçençia e facultad para que agora e de aquí adelante pudiésedes poner e traer en vuestras armas e reposteros, juntamente con las del dicho conde de Buendía, vuestro padre, o de por sí, como os paresçiere, los dichos dos castillos, o como la mi merçed fuese.

Y yo, por vos faser bien e merçed, acatando a los dichos serviçios e porque de vos e de vuestros serviçios aya memoria, y por los del dicho conde de Buendía, vuestro padre, tóvelo por bien. E por la presente vos fago merçed que podays / [fol. vuelto] traer e tener, e traygáys e tengáys, por vuestras armas conosçidas, juntamente con las del dicho conde de Buendía o de por sí, los dichos dos castillos en vn escudo a tal como éste ${ }^{136}$. E mando al yllustrysimo prínçipe don Carlos, mi muy caro e amado hijo, e a los ynfantes, perlados, duques, marqueses, condes, ricos onbres, maestres de las hórdenes, priores, comendadores e subcomendadores, alcaydes de los castillos e casas fuertes e llanas, e alcaldes del mi Consejo, oydores de las mis avdiençias, allcaldes, alguaçiles e otras justiçias qualesquier de la mi Casa e Corte e chançillerías; e a todos los corregidores, asystentes, governadores, allcaldes, alguaçiles, merinos e otras justiçias qualesquier, asy de la dicha villa de Caçorla como de todas las otras çibdades e villas e lugares de los mis reinos e señoríos, asy los que agora son como los que serán de aquí adelante, e a cada vno dellos, que vos guarden e cumplan, e hagan guardar e cumplir esta merçed que vos yo asy fago. Y en cumpliéndola dexen e consyentan traer e tener por las dichas armas en los dichos vuestros reposteros e en otras partes donde vos quisiéredes

\footnotetext{
${ }^{136}$ En la copia de la real provisión que quedó en el Registro General del Sello no se incluye el dibujo del escudo, pero sí en el pseudotraslado de 1572 que, convenientemente modificado, inserta también las armas de los Acuña, base de la falsificacion genealógica y heráldica que ha llegado hasta la actualidad.
} 
traerlas e ponerlas, a vos e a vuestros desçendientes. E las ayan e tengan por vuestras armas conosçidas. Y que en ello, ni en parte dello, enbargo ni contrario alguno vos no pongan ni consientan poner. Y si desto, que dicho es, quisierdes mi carta de previllegio, mando al mi chançiller, e notarios e a los demás ofiçiales que están a las tablas de los mis sellos, que vos la den, libren e pasen, tan firme e bastante como la vos quisiéredes e oviéredes menester; con tanto que primeramente tome la razón desta mi carta Francisco de los Cobos.

E los unos ni los otros non fagades ni fagan ende al por alguna manera, so pena de la mi merçed e diez mill maravedíes para la mi Cámara, a cada uno por quien fincare de lo así hacer e conplir. E demás, mando el ome que vos esta mi carta mostrare / [fol. recto] que vos enplase que parescades ante mí, en la mi Corte do quier que yo sea, del día que vos enplasare fasta quinse días primero siguientes, so la dicha pena. So la qual, mando a qualquier escribano público que para esto fuese llamado que demande al que vos la mostrase testimonio signado con su signo, porque yo sepa en cómo se cumple mi mandado.

Dada en la villa de Madrid, a quatro días del mes de enero, año del nacimiento de nuestro señor Ihesu Christo de mill e quinientos e onse años. Yo, el rey. Yo, Lope Conchillos, secretario de la reina nuestra señora la fize escribir por mandado del rey, su padre. Liçençiatus Çapata, Fernando Tello liçençiatus. Tomó la razón desta carta de Su Alteza, Francisco de los Cobos". 


\section{Bibliografía}

Acosta Echeverría, Manuel y Tristán García, Francisco: "El escudo de Baza: una representación de la realidad histórica (el cerco y la toma de 1489)", Péndulo. Papeles de Bastitania, 15 (2014), pp. 131-156.

Alonso García, David, "Las Comunidades de Castilla en el s. XXI", Tiempos modernos: Revista Electrónica de Historia Moderna, 19 (2009), http://www.tiemposmodernos.org/ tm3/index.php/tm/article/view/183/240, [24 enero 2020]

Aranda Pérez, Francisco José, Poder municipal y cabildo de jurados en Toledo en la Edad Moderna: (siglos XV-XVIII), Ayuntamiento de Toledo, Toledo, 1990.

Arco y Molinero, Ángel del, Glorias de la nobleza española: reseña histórica acerca de los caballeros principales que concurrieron a la conquista de Granada: bienes y honores que recibieron de los Reyes Católicos como recompensa de sus hazañas: armas y blasones de sus linajes: orígenes de su nobleza y casas ilustres españolas que descienden de aquellos conquistadores..., Establecimiento tipográfico de Aris e hijo, Tarragona, 1899. BAZÁn, Iñaki, "La pena de muerte en la Corona de Castilla en la Edad Media", Clio \& Crimen, 4 (2007), pp. 306-352.

Cabrera de Córdoba, Luis, Filipe Segundo, Rey de España al Serenísimo Príncipe su nieto esclarecido D. Felipe de Austria, Sucesores de Rivadeneyra, Madrid, 1876-1877, 4 vols.

CÁceres Pla, Francisco, "Moros y moriscos en España en el siglo XVI", La España moderna, 272 (agosto 1911), pp. 5-31.

Carriazo Arroquia, Juan de Mata, "La vida en la frontera de Granada: selección de estudios monográficos personales", Actas del I Congreso de Historia de Andalucía (diciembre de 1976): Andalucía Medieval, II, Monte de Piedad y Caja de Ahorros de Córdoba, Córdoba, 1982 (2a ed.), pp. 277-301.

Castillo Fernández, Javier, "El origen del concejo y la formación de la oligarquía ciudadana en Baza (1492-1520)", Chronica nova: Revista de historia moderna de la Universidad de Granada, 20 (1992), pp. 39-74.

Castillo Fernández, Javier, Macael y Laroya en la Alta Edad Moderna (1489-1650): conquista, época morisca y repoblación, Instituto de Estudios Almerienses, Diputación de Almería, Almería, 1998.

Castillo Fernández, Javier, "Conflictos y protestas populares en el reino de Granada (1504-1521)", Carlos V europeísmo y universalidad [congreso internacional, Granada mayo 2000], Francisco Sánchez-Montes González y Juan Luis Castellano (coords.), Sociedad Estatal para la Conmemoración de los Centenarios de Felipe II y Carlos V, Madrid, 2001, vol. 4, pp. 175-210.

CAstillo Fernández, Javier, "La rebelión de las Comunidades en el Reino de Granada: los casos de Huéscar y Baza", Uskar: revista histórica y cultural de la comarca, 5 (2002), pp.17-36. 
Castillo Fernández, Javier, “"Negocios de familia”: el perfil institucional y social de los mayordomos de propios del Reino de Granada (1492-1550)", Chronica nova: Revista de historia moderna de la Universidad de Granada, 31 (2005), pp. 23-64.

Castillo FernÁndez, Javier, "La articulación territorial del noreste del Reino de Granada de la Edad Media a la Moderna", Territorio e historia en el antiguo oriente granadino. Primer coloquio Alvelal. Huescár, 2016, Julián Pablo Díaz López y Andrés Sánchez Picón (eds.), Universidad de Almería, Almería, 2017, pp. 15-62.

Ceballos-Escalera Gila, Alfonso de y Cercós García, Luis F.: "Los españoles en la Orden de San Esteban de Toscana (caballeros, pretendientes, falsarios)", Cuadernos de Ayala: revista de la Federación Española de Genealogía y Heráldica y Ciencias Históricas, 36 (octubre-diciembre 2008), pp. 9-21.

Corral García, E., El mayordomo de concejo en la corona de Castilla (s. XIII-s. XVIII), El Consultor de los Ayuntamientos y de los Juzgados, Madrid, 1991.

Crespo Muñoz, Francisco Javier, El notariado en Baza (Granada) a comienzos de la Edad Moderna: estudio y catálogo de los protocolos notariales (1510-1519), tesis doctoral, Universidad de Granada, Granada, 2007.

Danvila y Collado, Manuel, Historia crítica y documentada de las Comunidades de Castilla, Memorial Histórico Español, Establecimiento tipográfico de la Viuda e hijos de M. Tello, Madrid, 1898-1899, 6 t.

Diago Hernando, Máximo, Le Comunidades de Castiglia (1520-1521). Una rivolta urbana contro la monarchia degli Asburgo, Unicopli, Milán, 2001.

Espinar Moreno, Manuel, "Partición de herencia de los repobladores bastetanos Juan Núñez de Alameda y Teresa de Boyça", Estudios sobre Patrimonio, Cultura y Ciencias Medievales, 17 (2015), pp. 31-54.

FERNÁNDEZ DE BÉTHENCOURT, Francisco, Historia genealógica y heráldica de la monarquía española: Casa real y grandes de España, Establecimiento tipográfico de Enrique Teodoro, Madrid, 1901.

García Guzmán, María del Mar, El adelantamiento de Cazorla en la Baja Edad Media: un señorío eclesiástico en la frontera castellana, Universidad de Cádiz, Cádiz, 1985.

González Dávila, Gil, Teatro de las grandezas de la villa de Madrid, Corte de los Reyes Católicos de España, Thomas Iunti, impresor, Madrid, 1623.

Gutiérrez Nieto, Juan Ignacio, Las comunidades como movimiento antiseñorial (la formación del bando realista en la guerra civil castellana de 1520-1521), Planeta, Barcelona, 1973.

Gutiérrez Cruz, Rafael y Martín Palma, María Teresa, "Documentos para el estudio de la población de Orán y Mazalquivir tras la conquista”, Baética: Estudios de arte, geografía e historia, 15 (1993), pp. 247-256.

HALICZER, Stephen, Los comuneros de Castilla. La forja de una revolución (1475-1521), Universidad de Valladolid, Valladolid, 1987. 
Hernández Franco, Juan y Jiménez Alcázar, Juan Francisco, “Estado, aristocracia y oligarquías urbanas en el reino de Murcia. Un punto de flexión en torno a las Comunidades de Castilla", Chronica nova: Revista de historia moderna de la Universidad de Granada, 23 (1996), pp. 171-187

Javierre Mur, Áurea Lucinda, Pruebas de ingreso en la Orden de San Juan de Jerusalén. Catálogo de las series de caballeros, religiosos y sirvientes de armas existentes en el Archivo Histórico Nacional, Archivo Histórico Nacional, Madrid, 1948.

JimÉnez AlCÁzAr, Juan Francisco, Un concejo de Castilla en la frontera de Granada: Lorca 1460-1521, Universidad de Granada, Granada, 1997.

Jiménez AlCÁzar, Juan Francisco, "En servicio del rey, en servicio de la Comunidad. Los comuneros en el reino de Murcia”, Murgetana, 103 (2000), pp. 33-42.

Jiménez Estrella, Antonio, Poder, ejército y gobierno en el siglo XVI: la Capitanía General del Reino de Granada y sus agentes, Universidad de Granada, Granada, 2004. Lafuente Alcántara, Miguel, Historia de Granada: comprendiendo la de sus cuatro provincias Almeria, Jaén, Granada y Málaga, desde remotos tiempos hasta nuestros dias, Imprenta y Librería de Sanz, Granada, 1843-1846, 4 tomos.

LÁzAro DAmas, María Soledad, "Poder y mecenazgo nobiliario en Baza: Doña María de Luna”, Péndulo. Papeles de Bastitania, 4 (2003), pp. 203-262.

LóPez de Haro, Alonso, Segunda parte del nobiliario genealógico de los reyes y títulos de España, Viuda de Fernando Correa de Montenegro, Madrid, 1622.

Magaña Visbal, Luis, Baza histórica, Tipografía La Providencia, Baza, 1927.

Maravall, José Antonio, Las Comunidades de Castilla: una primera revolución moderna, Alianza, Madrid, 1984, $4^{\mathrm{a}}$ ed.

MARTín CEA, Juan Carlos, "El modelo testamentario bajomedieval castellano y su reflejo en los diferentes grupos sociales", Edad Media: revista de historia, 6 (2003-2004), pp. 103-156.

Montojo Montojo, Vicente y Jiménez Alcázar, Juan Francisco, "Conflictos internos en la época de Carlos V: las Comunidades en la Región de Murcia”, En torno a las Comunidades de Castilla, Francisco Martínez Gil (coord.), Servicio Publ. Universidad de Castilla-La Mancha, Cuenca, 2002, pp. 431-460.

Miralles Lozano, María Eulalia y Tristán García, Francisco, "La repoblación de Baza: el repartimiento de los Reyes Católicos (introducción, compendio y propuestas de investigación)", Péndulo. Papeles de Bastitania, 15 (2014), pp. 185-210.

Muñoz y Gaviria, José, Historia del alzamiento de los moriscos, su espulsion [sic] de España y sus consecuencias en todas las provincias del reino, Establecimiento tipográfico de Mellado, Madrid, 1861.

Owens, John B., Rebelión, monarquía y oligarquía murciana en la época de Carlos $V$, Universidad de Murcia, Murcia, 1980. 
Paulino Montero, Elena, "Encuentro con lo sagrado y conmemoración familiar. Las ceremonias funerarias de los Velasco en Santa Clara de Medina de Pomar (1383-1471)", Codex aquilarensis: Cuadernos de investigación del Monasterio de Santa María la Real, 30 (2014), pp. 159-176.

Peinado Santaella, Rafael Gerardo, "El Reino de Granada después de la conquista: la sociedad repobladora según los "libros de repartimiento"”, La Península Ibérica en la era de los descubrimientos (1391-1492): actas III Jornadas Hispano-Portuguesas de Historia Medieval, Isabel Montes Romero-Camacho, Antonio Claret García Martínez y Manuel González Jiménez (coords.), Consejería de Cultura. Junta de Andalucía, Sevilla, 1997, vol. 2, págs. 1575-1630.

PÉrez, Joseph, La revolución de las Comunidades de Castilla (1520-1521), Siglo XXI, Madrid, 1977.

Pérez Boyero, Enrique, "Notas y documentos sobre las conversiones voluntarias de mudéjares granadinos al cristianismo (1482-1499)", Actas III Jornadas Hispano-portuguesas de Historia Medieval. La Península Ibérica en la Era de los Descubrimientos (1391-1492), Consejería de Cultura. Junta de Andalucía, Sevilla, 1997, pp. 1647-1670. Porras Arboledas, Pedro, Las comunidades conversas de Úbeda y Baeza en el siglo XVI, Instituto de Estudios Giennenses, Jaén, 2008.

Ruiz Povedano, José María, "Las élites de poder en las ciudades del reino de Granada", Las ciudades andaluzas (siglos XIII-XVI): Actas del VI Coloquio Internacional de Historia Medieval de Andalucía, José Enrique López de Coca y Ángel Galán (eds.), Universidad de Málaga, Málaga, 1991, pp. 357-415.

SAlazAr y Acha, Jaime de, Génesis y evolución histórica del apellido en España: discurso leído el día 26 de mayo de 1991 en el acto de su recepción pública, Real Academia Matritense de Heráldica y Genealogía, Madrid, 1991.

SANTA CRuz, Alonso de, Crónica del emperador Carlos $V$, edición de Ricardo Beltrán y Róspide y Antonio Blázquez, Real Academia de la Historia, Madrid, 1920-1925, 5 vols. SÁnchez Badiola, Juan José, Nobiliario de la Montaña leonesa, el autor, Atarfe, 2019. Soria Mesa, Enrique, "Los judeoconversos granadinos en el siglo XVI. Nuevas fuentes, nuevas perspectivas", Estudios sobre iglesia y sociedad en Andalucía en la Edad Moderna, Miguel Luis López Guadalupe Muñoz y Antonio Luis Cortés Peña (coords.), Universidad de Granada, Granada, 1999, pp. 101-109.

Soria Mesa, Enrique, "Tomando nombres ajenos. La usurpación de apellidos como estrategia de ascenso social en el seno de la élite granadina durante la época moderna", Las élites en la época moderna: la monarquía española, Enrique Soria Mesa, Juan Jesús Bravo Caro y José Miguel Delgado Barrado (coords.), Universidad de Córdoba, Córdoba, 2009, vol. 1, pp. 9-27.

TAPIA GARrido, Ángel, Historia General de Almería y su provincia: Almería Mudéjar (1489/1522), Monte de Piedad y Caja de Ahorros de Almería, Almería, 1989. 
Tristán GarCía, Francisco, "Baza, 1525: (un estudio de la sociedad a través de un padrón de cristianos viejos)", Chronica nova: Revista de historia moderna de la Universidad de Granada, 26 (1999), pp. 393-481

Tristán García, Francisco, "Enrique Enríquez, el primer repoblador de los Reyes Católicos", Los señoríos en la Andalucía Moderna. El Marquesado de los Vélez, Francisco Andújar Castillo y Julián Pablo Díaz López (coords.), Instituto de Estudios Almerienses, Almería, 2007, pp. 581-603.

Tristán García, Francisco, "Un patrimonio bastetano recuperado: las actas capitulares del Concejo de Baza (del 19 de agosto de 1513 al 18 de enero de 1514)", Péndulo. Papeles de Bastitania, 13 (2012), pp. 329-362. 